\title{
Reconstruction of geothermal boreholes in Poland
}

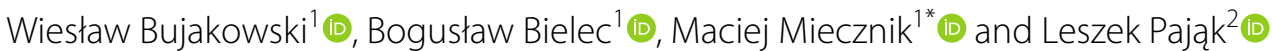

\author{
${ }^{*}$ Correspondence: \\ miecznik@min-pan.krakow.pl \\ ${ }^{1}$ Mineral and Energy \\ Economy Research Institute, \\ Polish Academy of Sciences, \\ Wybickiego 7A Str., \\ 31-261 Kraków, Poland \\ Full list of author information \\ is available at the end of the \\ article
}

\begin{abstract}
The beginnings of geothermal implementation research in Poland date back to 1989-1993 when the Mineral and Energy Economy Research Institute of the Polish Academy of Sciences (MEERI PAS) launched the first geothermal installation in the Podhale region, using the reconstructed Bańska IG-1 well. The knowledge acquired during these 30 years has highlighted the importance of geothermal energy-among other things, borehole reconstruction operations and the need for their further refinement. The technologies developed have been used in virtually all geothermal heating systems operating in Poland. Examples of successful reconstruction work include the Bańska IG-1 and Biały Dunajec PAN-1 wells operated by the PEC Geotermia Podhalańska S.A. geothermal company. The Mszczonów IG-1 well, which is operated by the Geotermia Mazowiecka S.A. heating company, has also undergone considerable work almost 24 years after its complete closure. Reconstruction processes can also be important in adapting existing wells for geothermal purposes. After World War II, more than 8000 boreholes deeper than $1000 \mathrm{~m}$ were drilled in Poland. They were primarily made for the purpose of geological surveys and hydrocarbon exploration. Some of these boreholes can be adapted for operation in geothermal systems. The paper presents selected methods of reconstructing abandoned, disused (not abandoned and not decommissioned) or damaged boreholes in order to use them in the geothermal water extraction process. Four examples of borehole reconstruction, designed and carried out with the participation of MEERI PAS in Kraków, are discussed in more detail.
\end{abstract}

Keywords: Geothermal systems, Borehole reconstruction, Deep wells in Poland

\section{Introduction}

Borehole reconstruction involves a number of technical and research measures which ultimately result in well and reservoir conditions that enable their commercial use. In terms of geothermal needs and goals, borehole reconstruction can be carried out in three areas, i.e.:

- the reconstruction of a damaged or decommissioned well;

- the restoration of an existing well;

- the repair of entire or part of an existing well.

Further, borehole reconstruction can be complete or partial.

\section{Springer Open}

(c) The Author(s) 2020. This article is licensed under a Creative Commons Attribution 4.0 International License, which permits use, sharing adaptation, distribution and reproduction in any medium or format, as long as you give appropriate credit to the original author(s) and the source, provide a link to the Creative Commons licence, and indicate if changes were made. The images or other third party material in this article are included in the article's Creative Commons licence, unless indicated otherwise in a credit line to the material. If material is not included in the article's Creative Commons licence and your intended use is not permitted by statutory regulation or exceeds the permitted use, you will need to obtain permission directly from the copyright holder. To view a copy of this licence, visit http://creativeco mmons.org/licenses/by/4.0/. 
Unused boreholes, which were drilled years ago, provide interesting opportunities in terms of their reconstruction. In many countries, there are several thousands of such boreholes. Relevant data can be found on websites of national geological units in the country in question or its online databases. For instance, in Poland, this information is available on the Polish Geological Institute-National Research Institute web services (PGI-NRI 2019a, b), and in Germany it is available on the Federal Institute for Geosciences and Natural Resources (BGR 2019) website. In the United States, data collected only in California indicate the number of over 140,000 wells. Most of these wells were plugged due to a decline of oil and gas productivity, while other wells were exploratory (Caulk and Tomac 2017). Well reconstruction can be a much better option for geothermal developers than drilling a new well. These benefits are associated with smaller financial outlays for works directly related to drilling as well as the construction of surface infrastructure. The lack of formal and administrative problems, which are usually long and burdensome in the case of drilling new wells, is also of great importance. The necessary condition for obtaining such benefits is the correct design and execution of reconstruction work (Caulk and Tomac 2017; Røksland et al. 2017; Nian and Cheng 2018a, b; Capuano 2016; Bujakowski 2015).

The correct reconstruction design is therefore crucial in the final economic effect of the project. One should not forget about the energy value additionally obtained through the use of heat pumps and the potential use of reservoir water. Chilled geothermal water can also be used as a drinking water directly from the well, for e.g., from wells in Mszczonów and Poddębice in Poland (Bujakowski 2015; Pająk et al. 2020), or after treatment with reverse osmosis technology (Tomaszewska 2008; Tomaszewska and Tyszer 2017; Tomaszewska et al. 2017; Tomaszewska and Dendys 2018). Abandoned deep wells can be also adapted to requirements of enhanced geothermal systems (EGS) or deep borehole heat exchanger (BHE) technology. In many countries low-temperature geothermal water are used to heat recreational pools and residential houses, greenhouse heating, breeding aquaculture species, water desalination or serve as a heat source to heat pumps (Kulcar et al. 2008; Goosen et al. 2010; Østergaard and Lund 2011). For these reasons, research is underway in many countries on the reuse of abandoned oil and gas wells. A valuable review of these activities is presented in the paper by Caulk and Tomac (2017). Authors report results of an investigation on the suitability of abandoned petroleum wells in California for EGS and low-temperature deep BHE applications.

Thousands of deep boreholes yielded, over several decades, rich geological information which was used to develop maps and atlases and write a number of geological articles related to geothermal energy. These articles concern the technologies used in conventional geothermal drilling (Barbier 2002), EGS installations (Lu 2018), and also in the appraisal of geothermal water resources (e.g., Fridleifsson and Freeston 1994). Detailed studies of geothermal resources were also performed at European scale (Haenel and Staroste (1988); Hurter and Heanel (2002); Hurter and Schellschmidt 2003), and national level, e.g., Germany (Agemar et al. 2014), Slovakia (Franko et al. (1995), and Ukraine (Gordienko and Gordienko (2004). In Poland, numerous high-quality geothermal atlases dealing with this subject were developed during last 30 years at scientific research units (Górecki 1990, 1995, 2006a, b, 2011, 2012, 2013, Barbacki et al. 2006; Solik-Heliasz 2009; Bujakowski and Tomaszewska 2014; Górecki et al. 2015). 
Since the end of World War II, more than 8000 boreholes deeper than $1000 \mathrm{~m}$ have been drilled in Poland. These wells were drilled mainly for two purposes, i.e., to meet the needs of the oil and gas industry and to recognize the geological structure and reservoir conditions. Drilling in Poland reached the highest intensity between 1966 and 1978 when more than 200 deep wells were drilled annually, while in the twenty-first century this was only 37 wells on average (Fig. 1). From the total number of 8416 deep wells in Poland, 5194 have depth between 1000 and $2000 \mathrm{~m}$ (61,7\%), 1870 wells have depth between 2000 and $3000 \mathrm{~m}(22,2 \%)$ and 1098 well are between 3000 and $4000 \mathrm{~m}$ deep $(13,0 \%)$. Only 254 wells are $4000 \mathrm{~m}$ deep or more, what constitute $3 \%$ of the total number of deep wells in Poland (Figs. 1, 2). Most of wells drilled for assessment of fossil fuels and mineral resources reserves are located on Carpathian Foredeep, Upper-Silesian Foredeep, Fore-Sudetic Monokline or southern part of East European Platform (Fig. 2). These units have rather poor or moderately good geothermal conditions (Górecki et al. 2015; Sowiżdżał 2018). Practically none of the boreholes drilled before 1989 were intended to facilitate geothermal water resource exploitation. Therefore, their structure, and especially casing, prevents their simple adaptation for geothermal purposes. The borehole completion date and the technical skills of the unit which drilled it are important indications when assessing the feasibility of borehole reconstruction. The wells completed in the 1990s and later were drilled with the use of modern technologies of accessing reservoir zones as well as of developing reservoirs, water extraction and testing. This group of wells could potentially be suitable for reconstruction in order to be used for geothermal purposes.

The wells drilled under the supervision of the Polish Geological Institute-National Research Institute (PGI-NRI) were commissioned mostly for research purposes (exploring geological structures and reservoirs). For this reason, they typically

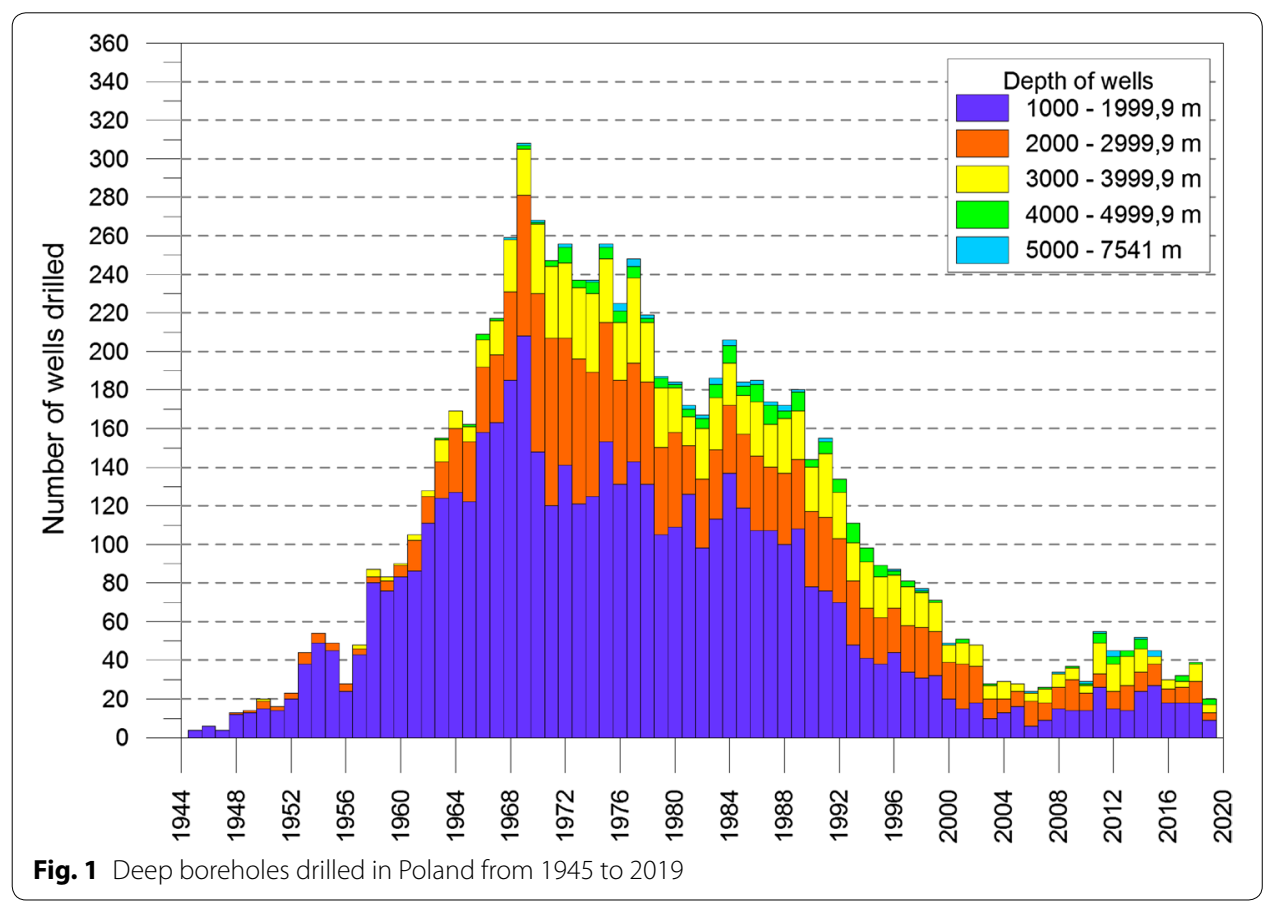




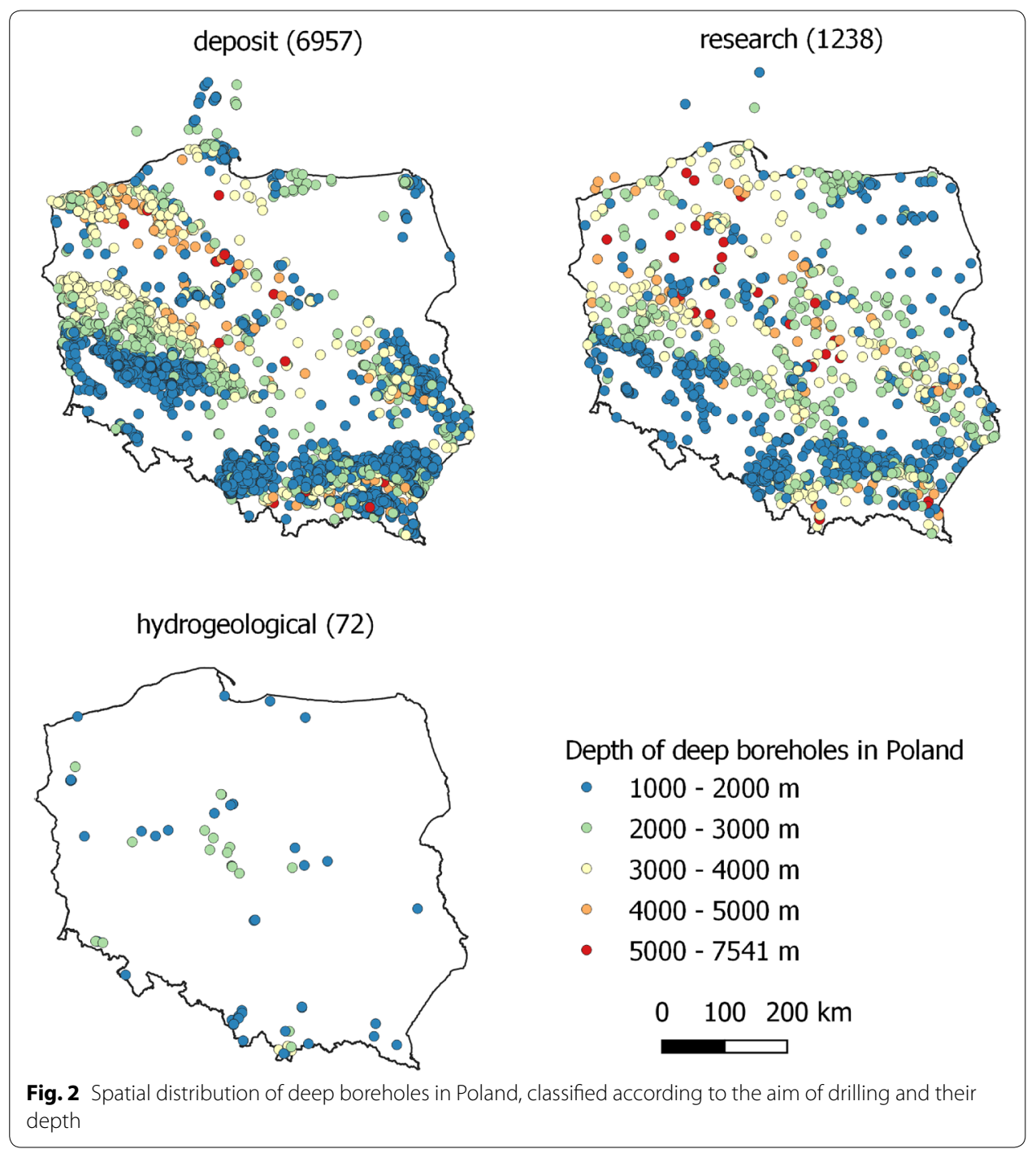

reached greater depths, had larger diameters and were tested in more detail compared to those drilled for the oil industry. In this context, PGI-NRI wells are more useful in terms of their planned development, although in some cases oil wells can also be reconstructed, as demonstrated by the Kompina 2 oil well reconstruction project (Bujakowski et al. 2009). Of these several thousand deep boreholes, it is estimated that only a small percentage are suitable for reactivation and development for geothermal purposes. For example, in the Piotrków district (central Poland), out of more than 50 extant deep boreholes only 10 have been identified on the basis of preliminary evaluation as presenting potentially feasible reconstruction opportunities (Bujakowski (2014). It can be stated with considerable certainty that this number will be further reduced at the stage of detailed analyses of well documentation. Even assuming that only a small percentage of extant wells would be suitable for reconstruction, their number is still sufficiently high that their development post-reconstruction could be very important for environmental reasons and perhaps also attractive in commercial terms. 


\section{A brief overview of geothermal conditions in Poland}

Poland has rich low-temperature geothermal resources, suitable for district heating, recreation and balneotherapy. The largest in area and the most perspective geothermal province in Poland is the Polish Lowlands province, which cover major part of the country (Fig. 3). Lower Cretaceous and Lower Jurassic reservoirs are the most valuable and most of existing geothermal installation in central and north-western part of Poland draw waters from one of these formations. These are the porous aquifers, mostly build from sandstones, locally also from carbonates (Sowiżdżał 2018). Geothermal water flowrates from single wells vary from several to locally over $300 \mathrm{~m}^{3} / \mathrm{h}$, but discharges even up to $450 \mathrm{~m}^{3} / \mathrm{h}$ are possible (Górecki 2006a; Sowiżdżał 2018). Wellhead temperature of these waters range from 20 to $94{ }^{\circ} \mathrm{C}$ (the latter value in the axial part of the MogilnoŁódź Trough, at a depth ca. $2.6 \mathrm{~km}$ ), but geothermal waters with temperature up to

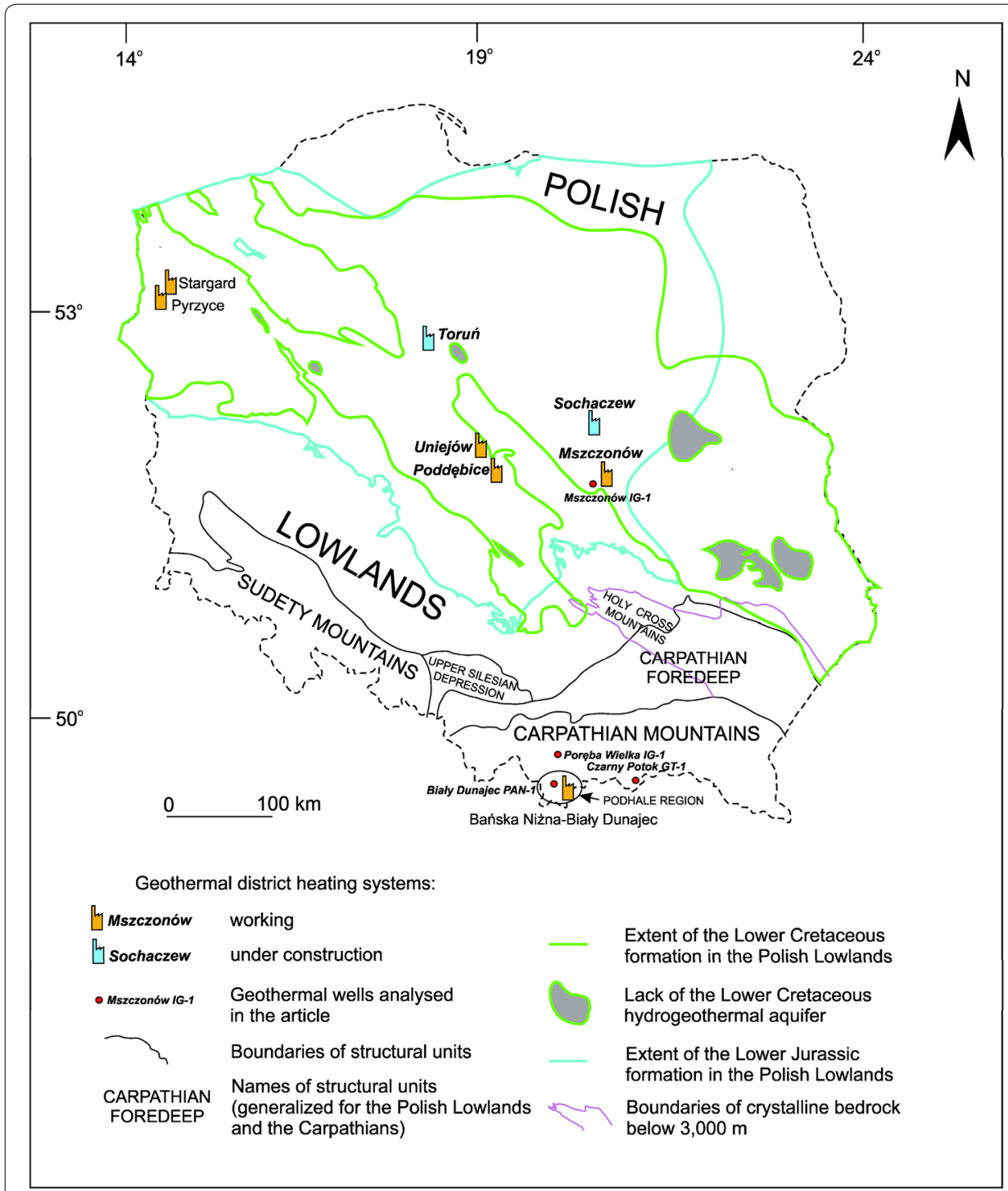

Fig. 3 Map of main geothermal provinces in Poland 
$120-130{ }^{\circ} \mathrm{C}$ are expected at greater depths (ca. $4 \mathrm{~km}$ ). Significant resources of geothermal energy are also stored in the Upper Jurassic, Middle Jurassic, Upper Triassic and Lower Triassic formations of Polish Lowlands. While the geothermal waters produced from the Lower Cretaceous strata are usually low mineralized (TDS from less than $1 \mathrm{~g} /$ $\mathrm{dm}^{3}$ to $50 \mathrm{~g} / \mathrm{dm}^{3}$, locally also in excess of $100 \mathrm{~g} / \mathrm{dm}^{3}$; Pająk et al. 2020), waters drawn from the Lower Jurassic formation often exceed $100 \mathrm{~g} / \mathrm{dm}^{3}$, and locally even over $250 \mathrm{~g} /$ $\mathrm{dm}^{3}$. High mineralization of these waters pose a significant problem for geothermal installation due to high susceptibility to corrosion. Five out of six geothermal district heating plants in Poland are located in the Polish Lowland province and a few more are planned or under construction (Fig. 3).

The next perspective region for further development of geothermal energy use in Poland is the Podhale geothermal system located in the Inner Carpathians (Fig. 3). The main geothermal aquifer is built from Mesozoic (mainly Triassic) limestones and dolomites, sometimes covered by Middle Eocene carbonates. Reservoir has low natural porosity, therefore fractures and deep faults are a key mechanism for water inflow to boreholes. So far, 15 geothermal wells have been drilled, but new ones are planned. The depth of these boreholes varies in a wide range from $680 \mathrm{~m}$ to ca. $3600 \mathrm{~m}$, due to the significant lowering of the main aquifer from the south to the north and west. Reservoir thickness is the highest in the central part of the system, reaching ca. $700 \mathrm{~m}$, of which effective thickness is around $100 \mathrm{~m}$. Approved operational resources from single well range from 4 to $550 \mathrm{~m}^{3} / \mathrm{h}$ (six of them have capacity exceeding $100 \mathrm{~m}^{3} / \mathrm{h}$ ). Most wells are self-flowing due to high artesian pressure (up to $27 \mathrm{bar}$ ). Wellhead temperature of produced water varies from $20^{\circ} \mathrm{C}$ in the southern part of the system up to $90{ }^{\circ} \mathrm{C}$ in the central and western part (Kępińska 2006; Miecznik 2017; Bielec and Operacz 2018). Waters' mineralization ranges from below 1 to ca $3 \mathrm{~g} / \mathrm{dm}^{3}$. In case of deeper aquifer (poorly recognized so far) measured formation water temperature was ca. $120{ }^{\circ} \mathrm{C}$ (depths ca. $4.8 \mathrm{~km}$, no exploitation so far; Kępińska 2006). The largest geothermal heating plant in Poland (40.7 MW of geothermal installed capacity, 82.6 MW total) is exploiting waters from the "Podhale 1" mining area located in the central part of the Podhale geothermal system. At the same time it is one of the biggest geothermal heating plants in continental Europe with advanced plans for capacity increase.

Other geothermal regions in Poland-Outer Carpathians, Carpathian Foredeep and the Sudetes Mountains (Fig. 3) are less prospective and therefore are not described here. Interested readers can find very detailed information and maps (except Sudetes Mountains province) in geothermal atlases (Górecki et al. 2012, 2013).

\section{Reconstruction types}

In the last few dozen years, several well reconstruction projects were developed in Poland with the aim of adapting the boreholes in question for geothermal system purposes. Out of this group of projects, only in a few cases was reconstruction work successfully carried out. The wells which were reconstructed or with respect to which reconstruction was planned can be divided into four groups depending on the scale and scope of the work performed. Presented below is a list of selected deep wells which undergo successful reconstruction for geothermal purposes or for which reconstruction projects were prepared but were ultimately not implemented. Most of these wells were 
developed by specialists from the Mineral and Energy Economy Research Institute of the Polish Academy of Sciences (MEERI PAS).

Group I. Decommissioned wells. These are wells that were decommissioned after drilling and the surrounding site was reclaimed, e.g.:

- the Mszczonów IG-1 well (drilled and decommissioned in 1977, reconstructed in 1999, trouble-free operation since 2000); reconstruction works are described in the further part of the article;

- the Kompina 2 well (drilled and decommissioned in 1981, a reconstruction project was prepared in 2009 but was not implemented).

Group II. Abandoned wells. These are wells which have not been decommissioned and surface equipment has been left in place; they sometimes access documented geothermal water resources; this group includes e.g.:

- the Bańska IG-1 well (drilled in 1981, reconstructed and commissioned as part of the first geothermal installation in Poland in 1993);

- 3 wells in Uniejów (Uniejów IGH-1 from 1978, Uniejów PIG/AGH-1 and Uniejów PIG/AGH-2 from 1990/1991-commissioned in 2001);

- the Poręba Wielka IG-1 well (drilled in 1975, reconstructed in 2012); reconstruction works are described in the further part of the article);

- the Skierniewice GT-1 and Skierniewice GT-2 wells (drilled in 1991 and 1997, respectively, with a plan for their utilization from 2011 and a reconstruction design from 2018, which is currently being implemented).

Group III. Damaged wells. These are wells which were worn out or suffered failures during a doublet system (production and injection well) operation or wells where reservoir parameters significantly deteriorated, e.g.:

- the Biały Dunajec PAN-1 well (drilled in 1990, commissioned in 1993, partly repaired in 2011; in 2014, the well was directionally deepened and restored to operation); reconstruction works are described in the further part of the article;

- 4 wells in Pyrzyce (drilled after 1992, commissioned as part of a geothermal plant in 1997, subsequently modified and repaired several times);

- the Stargard Szczeciński GT-2 well (drilled in 2005, repaired and operated as part of a geothermal plant since 2012).

Group IV. Negative wells. Wells which failed to achieve their geological goal are cased and include surface equipment, e.g.:

- the Czarny Potok GT-1 well in Krynica (drilled in 2011, no documented geothermal water resources were found; in 2012, a plan was developed to convert the well into a coaxial heat exchanger, but the project was not implemented), the assumptions underlying the reconstruction plan are described in the further part of the article.

The scope of reconstruction work differed for each of the wells listed above. When drawing up geological work designs, not just local geological and hydrogeothermal 
conditions (including hydrogeological and thermal parameters) but also the parameters required with respect to the energy recipient were taken into account in each case.

\section{Examples of completed borehole reconstructions}

This section describes the reconstruction of selected deep boreholes in Poland for the purpose of geothermal energy exploitation. Their locations are shown in Fig. 3.

\section{Mszczonów IG-1 well}

The reconstruction of the Mszczonów IG-1 well, which was completely decommissioned and the drilling site was fully reclaimed to the extent that a market operated in the place where the well used to be, was the most extensive project. It was the first reconstruction with such a large scope in Poland. The Mszczonów IG-1 well was drilled in 1976-1977 within the framework of the "Projekt badań geologicznych w synklinorium warszawskim i na antyklinorium kujawskim" (eng. "Warsaw Synclinorium and Kujawy Anticlinorium geological research project"). The aim of that programme was to study the opportunities offered by the Early Mesozoic, Permian and pre-Permian Palaeozoic reservoirs in the contact zone between the Precambrian and Palaeozoic platforms.

The primary purpose of the Mszczonów IG-1 well was to identify the facial variability of the Main Dolomite within the Warsaw Trough. Before reaching its final depth of 4119 m, the Mszczonów IG-1 well was drilled through Mesozoic and Permian formations as well as several dozen layers of Carboniferous formations. Reconstruction work started in 1996 on the basis of the technical design drawn up by the POLGEOL company and the methodology developed by MEERI PAS. The well was reconstructed in order to restore its proper technical condition and also to determine an environmentally safe rate of geothermal water extraction from Lower Cretaceous sandstone formations (Bujakowski 2000, 2015). The technical condition of the well pre- and post-reconstruction is shown in Fig. 4. The interval included in the reconstruction reached the depth of $1793 \mathrm{~m}$ b.g.l. where the top of the cement plug is located.

The reconstruction process included technical work and studies aimed at ensuring that the technical condition of the well was safe and geothermal waters could be extracted from the Lower Cretaceous aquifer.

I. Technical work, which included:

- drilling works and securing the well;

- making the reservoir accessible;

- installations and operating equipment.

II. Studies and reservoir tests including:

- flushing;

- measurement pumping (step-drawdown test);

- pre-operation pumping;

- hydrodynamic tests;

- geophysical studies of absorption zones; 


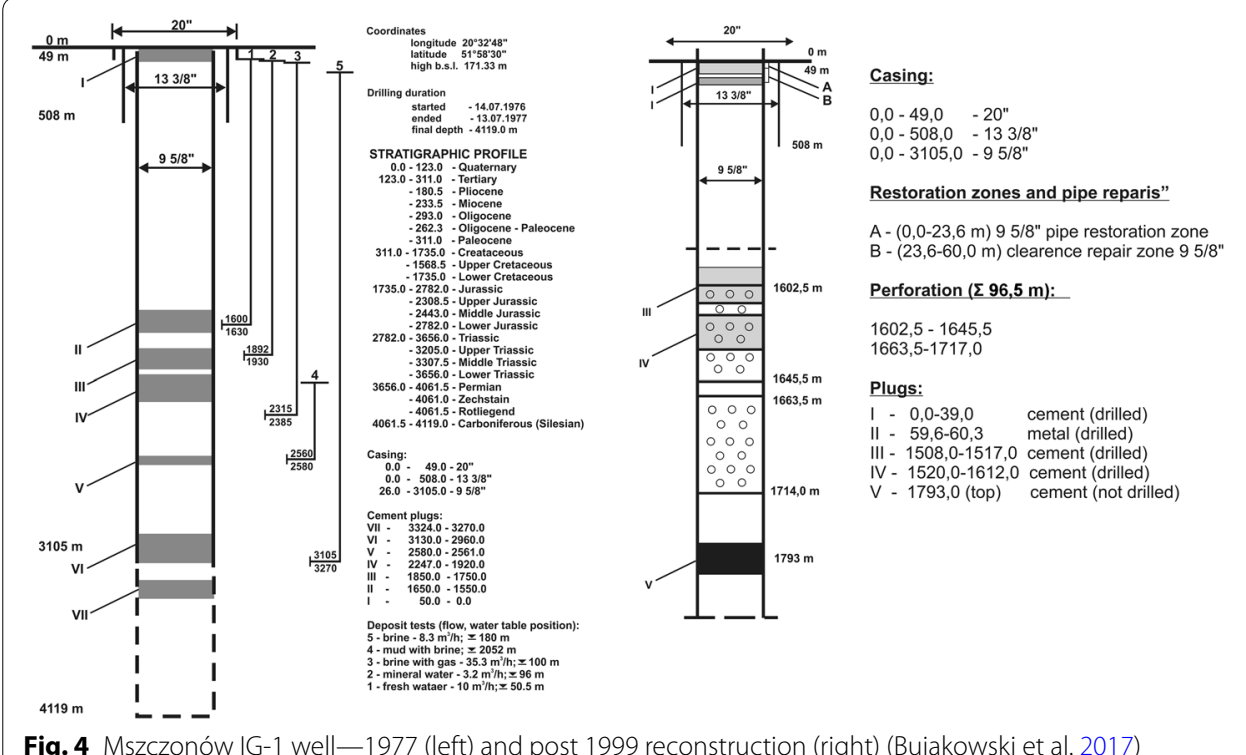

- examination of well technical condition;

- physico-chemical analysis of waters;

- mineralogical and petrographic studies;

- isotope analysis of waters.

Technical drilling work mainly concerned the drilling of cement plugs, flushing the well, testing whether the well is not obstructed using a lead impression block, diagnosing and eliminating casing defects. The final stage of this work consisted in the perforation of casing within a selected interval (1602.5-1645.5 and 1663.5-1714.0 m).

These technical procedures, whose scope could not have been fully predicted at the stage of drawing up the reconstruction project due to the absence of any records from the drilling and decommissioning stages, played a key role in effectively repairing the well, which guaranteed its long-term operation as a source of energy for a district heating system. Casing damage was diagnosed with the use of a camera and MAC-80 and MIT-60 multi-finger imaging tools. The images obtained during the tests made it possible to inspect visually any given casing section. Particular attention was paid to the 0-95 m interval, where there was damage to casing at depths of around 5, 23 and $59 \mathrm{~m}$ (Figs. 5, 6). In the 24-46 m interval, a slight deviation between the profiles obtained using the multifinger imaging tool was found, which was evidence of casing ovality. A discrepancy was also found in the depth measurement records made in 2001 (incorrect depth correlation at the casing collar under the wellhead). In order to correct the depth scale of MAC-80 logging and to explain the defects in casing present at the depths of 23 and $59 \mathrm{~m}$, an additional measurement was made with a MIT60 multi-finger caliper from the wellhead down to the depth of $109 \mathrm{~m}$. The damage at the depth of $23 \mathrm{~m}$ was repaired by the insertion of a supplementary casing section (Fig. 5), (Bujakowski et al. 2013a). Casing damage found at a depth of approximately $59 \mathrm{~m}$ was identified and repaired by milling the casing (Fig. 6). 


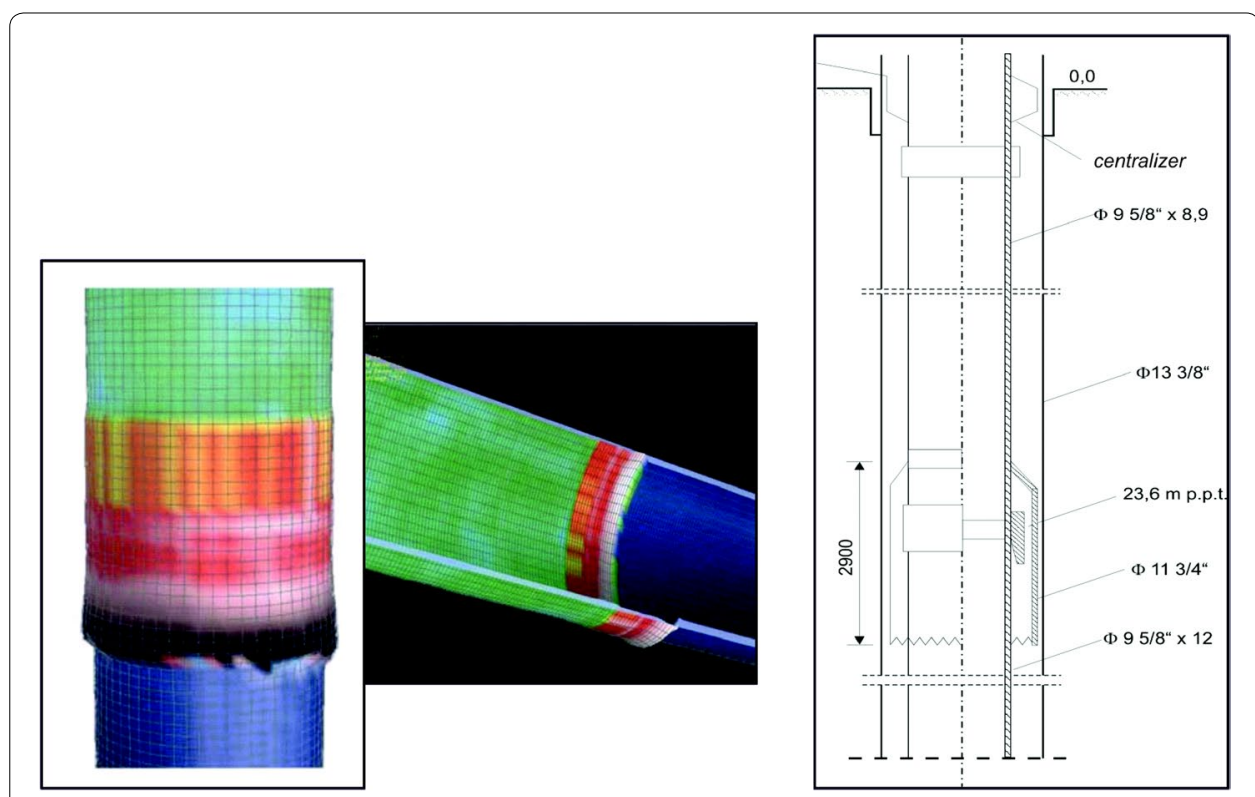

Fig. 5 Picture of casing repair at a depth of $23 \mathrm{~m}$ (left: casing joints-image from the MIT probe from 2003, right: supplementary casing design from 1999) (Bujakowski et al. 2013a)
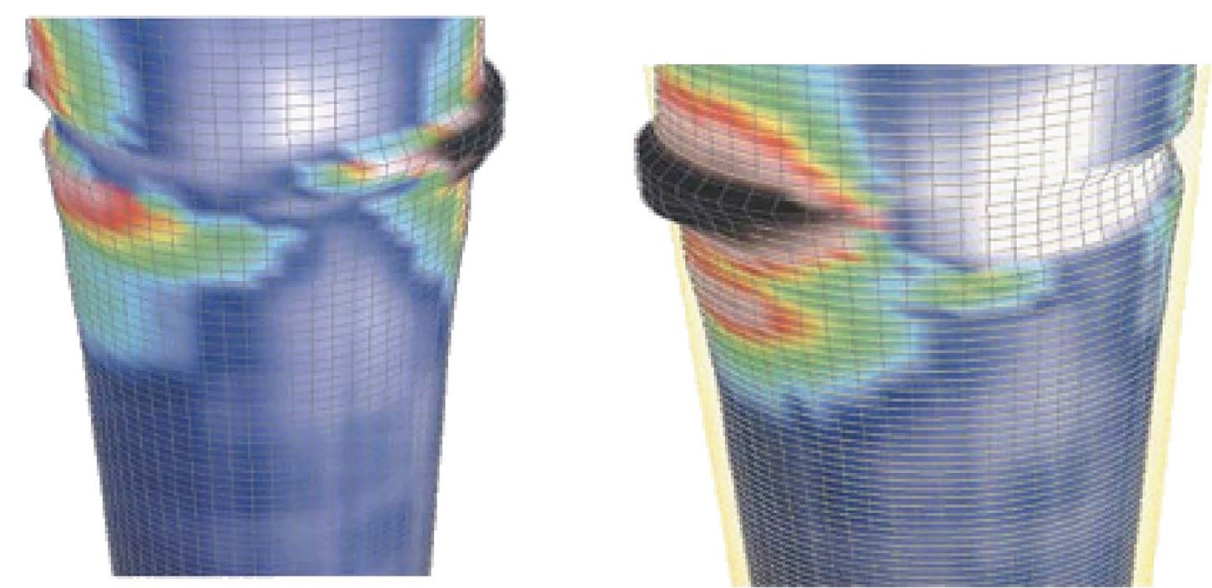

Fig. 6 Casing damage at a depth of 59 m—image from the MIT-60 probe from 2003 (Bujakowski et al. 2013a)

The zones listed above are periodically monitored using geophysical borehole probes as described in Bujakowski et al. 2013a. A summary of the results of casing pipe inspections conducted using the MIT-60 probe is shown in Fig. 7. The image shows the minimum, maximum and mean diameter changes recorded in 2003 (marked as MIND03/2, MAXD03/2 and AVED03/2 in the figure) and changes in minimum, maximum and mean pipe radius (as captured in 2003 and 2012 tests) (marked as MINR03, MAXR03, MINR12, MAXR12 and AVER12/2 in the figure). The above curves are shown against the inner and outer radius of the pipe (wall thickness) estimated on the basis of the documentation concerning the materials used in 1977. These are marked as O.R. (outer pipe radius) and I.R. (inner pipe radius). Curves 


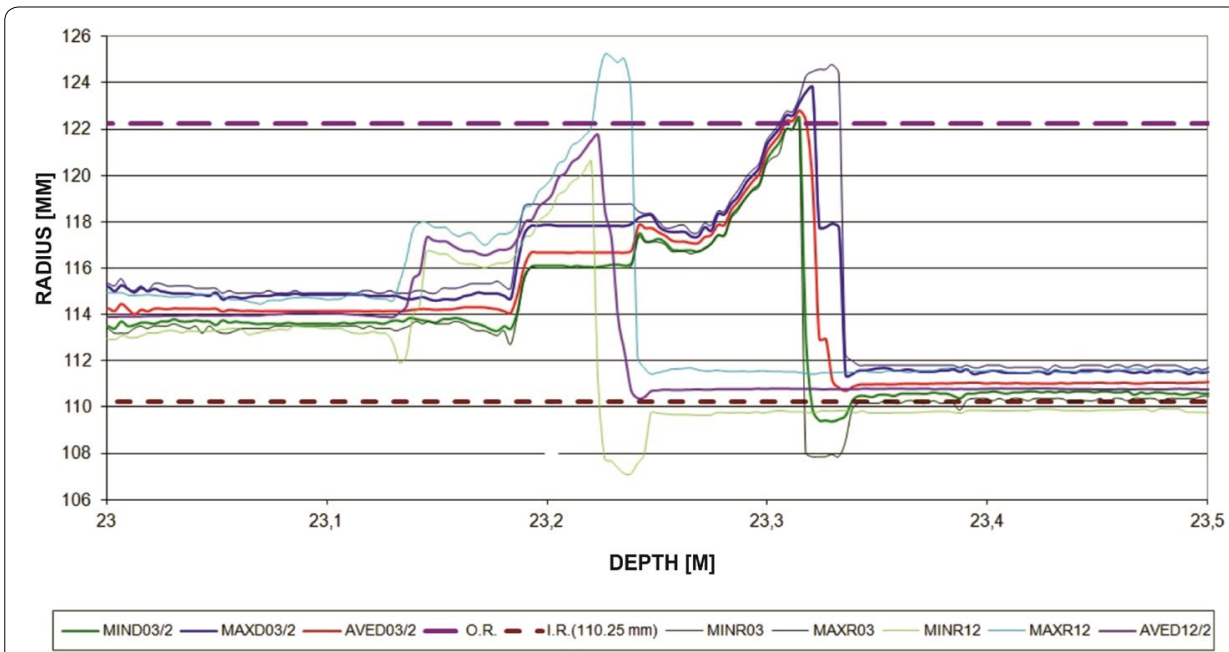

Fig. 7 Comparative graph of pipe radius and pipe diameter testing using the MIT60 probe at a depth of approximately 23 m, 2003 and 2012 (Bujakowski et al. 2013a)

Table 1 Summary of step-drawdown test (measurement pumping) results (Bujakowski (2000)

\begin{tabular}{|c|c|c|c|c|c|}
\hline Flow rate $\left(\mathrm{m}^{3} / \mathrm{h}\right)$ & Pumping time & $\begin{array}{l}\text { Lowest level } \\
\text { of the water table } \\
\text { ( } \mathrm{m} \text { b.g.l.) }\end{array}$ & Depression $(\mathrm{m})$ & $\begin{array}{l}\text { Unit } \\
\text { efficiency } \\
\left(\mathrm{m}^{3} /(\mathrm{h} \cdot \mathrm{m})\right)\end{array}$ & $\begin{array}{l}\text { Temp. at the end } \\
\text { of pumping }\left({ }^{\circ} \mathrm{C}\right)\end{array}$ \\
\hline 29.0 & 29 h $30^{\prime}$ & 67.46 & 14.46 & 2.01 & 36.6 \\
\hline 56.0 & 47 h $45^{\prime}$ & 91.73 & 38.73 & 1.45 & 39.3 \\
\hline From 69.0 to 75.0 & $442 \mathrm{~h}$ & 107.3-79.09 & $54.3-26.09$ & $1.27-2.87$ & 40.5 \\
\hline
\end{tabular}

which exceed an outer radius of $122 \mathrm{~mm}$ and an inner radius of $110 \mathrm{~mm}$ mean damage to the pipe wall and its repair as shown in Fig. 7.

One of the major reconstruction tasks was to determine the production flow rate of geothermal water which would be environmentally safe. As concerns the research carried out, reservoir test and studies tests should be mentioned. These included well flushing, measurement pumping, pre-operation pumping, hydrodynamic tests and geophysical surveys of reservoir zones. Selected results obtained during measurement pumping are presented in Table 1 (Bujakowski (2000).

Detailed studies of the reservoir zone were carried out with the use of a comprehensive production logging (PL), which included the following components:

- casing collar locator (CCL);

- gamma ray tool (GRT);

- temperature logging tool (TLT);

- stack pressure tool (SPT);

- fullbore flowmeter (FBF).

The purpose of production logging of geothermal water feed zones is to:

- assess the productivity of individual intervals (in terms of their percentage shares); 
- assess inflows from individual intervals within the reservoir complex;

- determine the location of non-productive zones (possibly using renewed perforation or other procedures to clear the well's horizons);

- determine the thickness of the effective reservoir zone to assess reservoir productivity.

Logging the reservoir zone with a production log is included in the scope of monitoring and three cycles of such logging were carried during the reconstruction (on 7 March 199720 June 1997 and 13 July 1999); additional logging inspections were carried out in 2003 (28 May) and 2012 (7 November) (Bujakowski et al. 2013b)-Fig. 8. The FBF flowmeter measures the velocity of well fluids using a spinner impeller. Upward movement of the flowmeter in the wellbore causes the spinner to rotate in proportion to the measurement speed or velocity of fluid entering the well. On the production log chart, production interval can be recognized as a zone of increased rotation velocity of a spinner. Constant spinner velocity (vertical or nearly vertical line on production log chart) is due to the constant measurement speed, therefore increase in the rotational speed of a spinner can be linked to the inflow of water from reservoir to the wellbore.

A comparison of analyses of measurements from previous years demonstrates (Fig. 8) that the well's productivity (assessed in a system where water is injected into the two absorption zones made available by perforation) does not change significantly over time, except for the first cycle of testing when no absorption capacity was found in the lower perforation interval. As a result of these studies, the productivity of the

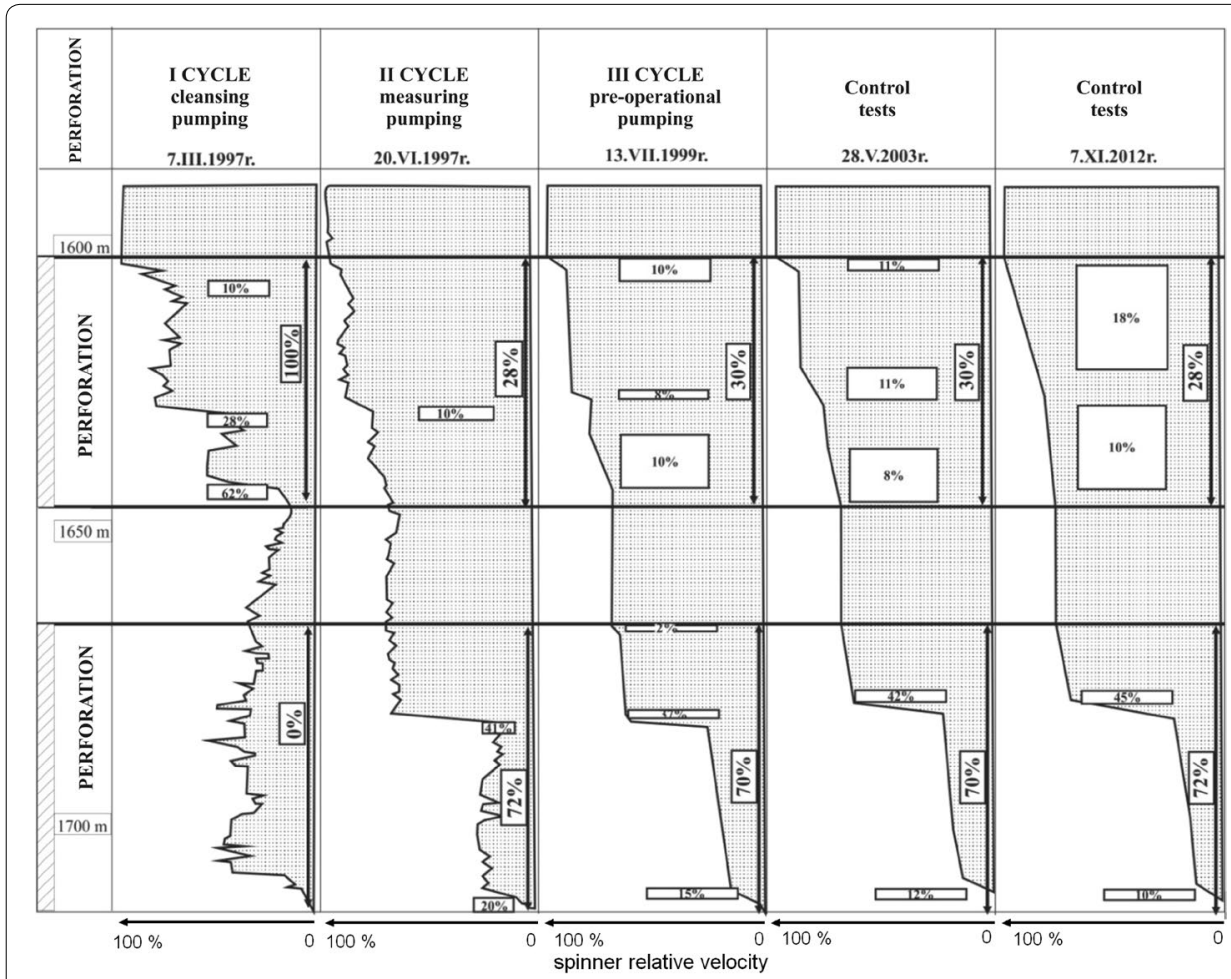

Fig. 8 Summary of production logging results from 1997, 1999, 2003 and 2012 (Bujakowski et al. 2013b) 
lower reservoir zone was assessed at around $70 \%$ and that of the upper zone at around $30 \%$ of the total. The tests conducted show that the greatest step change in the well's productivity occurs at a distance of just several centimeters at a depth of approximately $1680 \mathrm{~m}$ (Bujakowski et al. 2013b). Data on physical and chemical properties of geothermal waters as well as on the intensity of sand migration from the reservoir were obtained from specially established test sites.

The following conclusions may be made on the basis of the tests conducted:

- the Lower Cretaceous geothermal reservoir exhibits high water production rate and temperature stability;

- the migration of sand from the reservoir is small and decreases quickly during intensive pumping;

- the pressure and temperature of reservoir water are quickly restored;

- results of water chemical analyses indicate that it can be approved for use as a drinking water (this eliminates the problem of water disposal after using it as a heat source);

- casing tests indicate its good condition despite its age and its different original purpose.

The Mszczonów IG-1 well has been operated in a single-well arrangement since 2000 and the water produced is used for heating, as drinking water and for bathing. As a result of the reconstruction work carried out, geothermal water resources have been documented with the following parameters:

- production rate: $60 \mathrm{~m}^{3} / \mathrm{h}$;

- depression $S: 24.6 \mathrm{~m}$;

- temperature: $41.5^{\circ} \mathrm{C}$;

- mineral content: $490 \mathrm{mg} / \mathrm{dm}^{3}$;

- water type: $\mathrm{HCO}_{3}-\mathrm{Cl}-\mathrm{Na}-\mathrm{Ca}$;

- static water table at a depth of $49 \mathrm{~m}$ b.g.l.

The parameters documented are continuously monitored during well operation. Figure 9 presents a summary of selected basic reservoir operation parameters in 2018 . The graphs indicate the stable operation of the geothermal system.

In 2017 and 2018, Geotermia Mazowiecka S.A. together with MEERI PAS in Kraków and the Warsaw University of Technology carried out a research project entitled "Development of a method for injecting spent geothermal waters into selected geological structures" co-financed from the 2014-2020 Regional Operational Programme of the Mazowsze Province (Priority Axis: Company R\&D Activities). The idea underlying the project was the storage of spent (cooled) geothermal water meeting requirements for drinking water in shallow aquifers. For these purposes, a Quaternary aquifer situated at a depth of up to $100 \mathrm{~m}$ was picked in the Mszczonów area. On the basis of existing geological data, a model of groundwater flows in the selected aquifer was developed. Subsequently, one injection well and two observation wells were designed and drilled (Bujakowski et al. 2020). After several months of research 


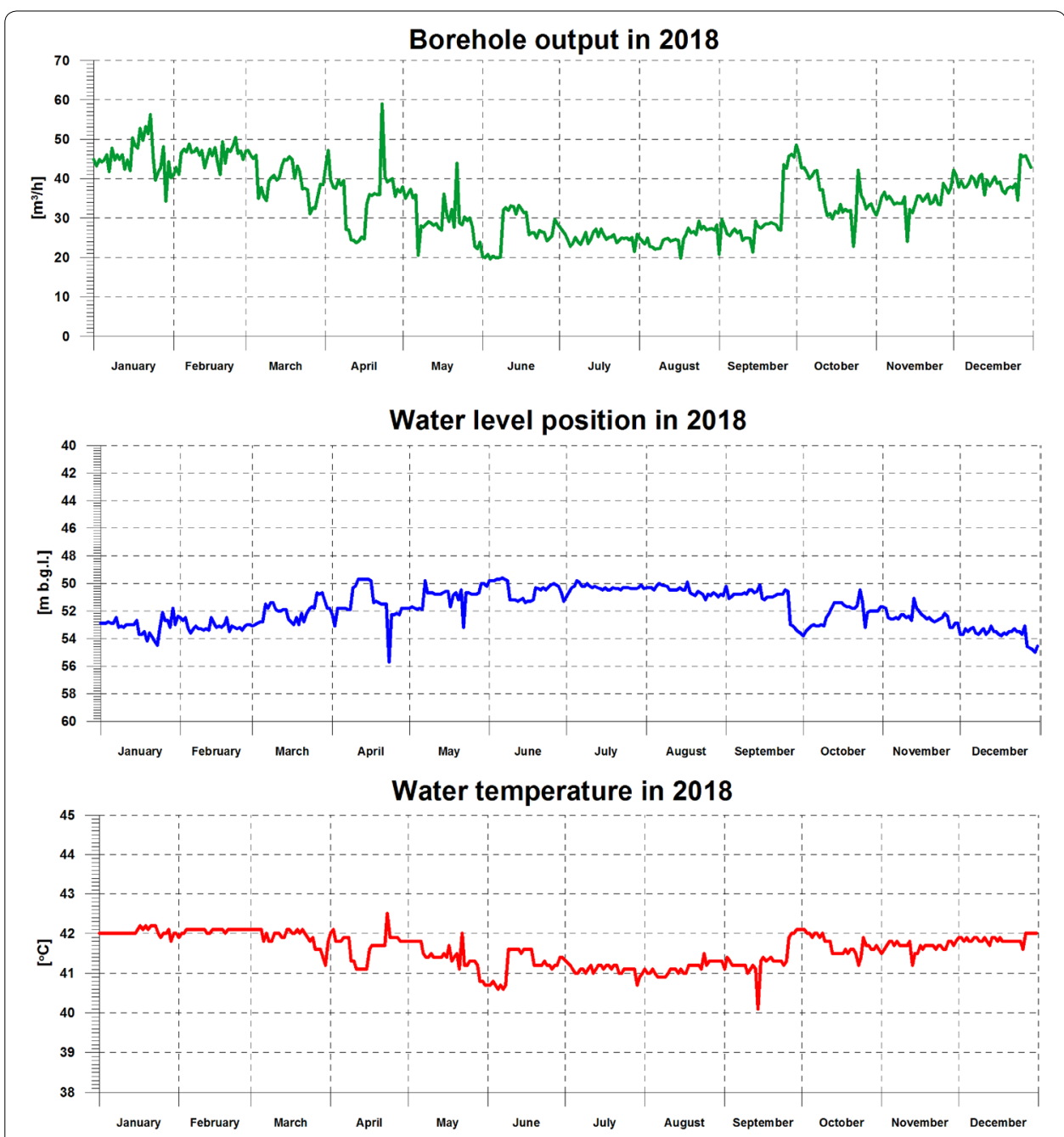

Fig. 9 Summary of monthly measurements of Mszczonów IG-1 geothermal well operation parameters (extraction rate, water table and water temperature)

and tests, which demonstrated no negative impact of geothermal water injection on the environment, all necessary administrative decisions and permits were obtained, including the environmental decision for the project and the water law permit for water injection. Research is currently underway in order to optimize the operation of the entire system.

\section{Poręba Wielka IG-1 well}

The Poręba Wielka IG-1 well was drilled from 1973 to 1975. The well provided access to a geothermal water (brine) aquifer in the series belonging to the Mszana Dolna tectonic window (Flysch Carpathians) in inoceramic layers (Upper Cretaceous-Paleocene) in the 1804.0-2002.4 m interval. On 5 November 1976, the geothermal water resources were approved with the following parameters: $Q=12.1 \mathrm{~m}^{3} / \mathrm{h}$ (artesian flow) with a wellhead 


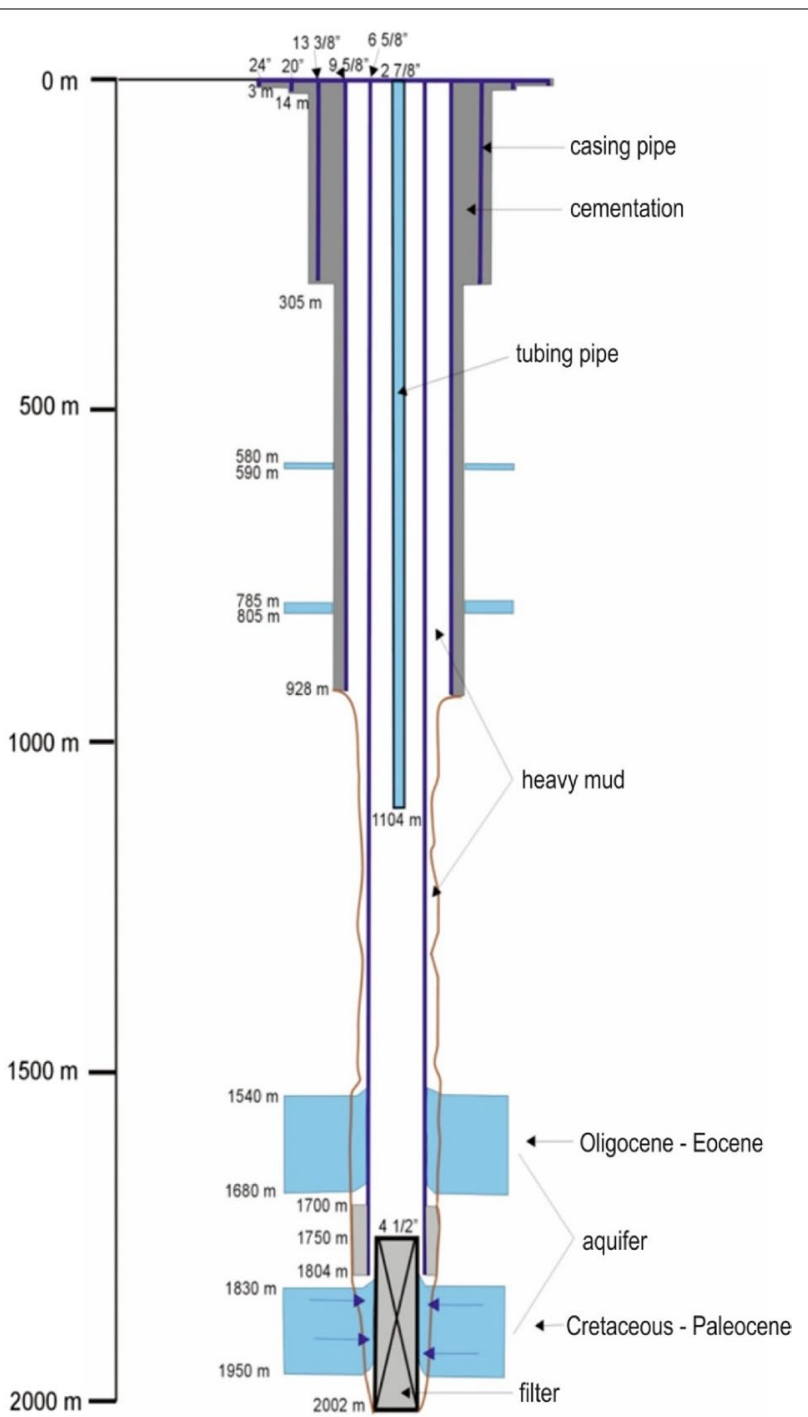

Fig. 10 Schematic structure of the Poręba Wielka IG-1 well in its pre-reconstruction state (Bujakowski et al. 2013c)

temperature of $42{ }^{\circ} \mathrm{C}$ and mineral content of approx. $22 \mathrm{~g} / \mathrm{dm}^{3}$ (Poprawa et al. 1975). After its completion and testing in 1975, the Poręba Wielka IG-1 well remained disused.

In 2010, after 35 years, MEERI PAS developed the "Geological works project in order to update geothermal water resources for the Poręba Wielka IG-1 well" (Bujakowski et al. 2010). The aim of the project was to extract geothermal waters for balneological and recreational purposes. The purpose of the works planned was to confirm the approved in 1976 production rate for geothermal water resources in the Poręba Wielka IG-1 well, or alternatively to determine if more water could be extracted from the well.

This is an example of reconstruction of a disused well which had neither been decommissioned nor operated since its construction. The schematic structure of the borehole in its pre-reconstruction state is shown in Fig. 10.

First, in order to balance the wellhead pressure (approx. 5.5 MPa), brine with a specific gravity of approx. $1.4 \mathrm{~g} / \mathrm{dm}^{3}$ was injected through the existing wellhead (Fig. 11) and 


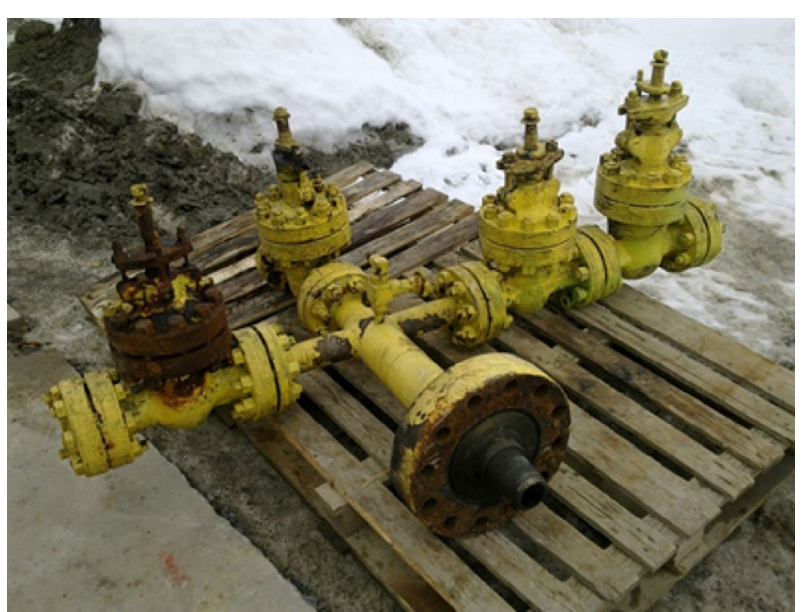

Fig. 11 Dismantled old wellhead of the Poręba Wielka IG-1 well (photo: B. Bielec)

$2^{7} / 8_{8}^{11}$ siphon tubes were sunk down to a depth of $1104.1 \mathrm{~m}$. Subsequently, the upper part of the wellhead was dismantled, a blowout preventer was installed and the $2^{7} / 8$ " tubes were pulled out.

The next step was well drifting using lead impression block, done in order to check whether the casing is not obstructed and the well is clear. The borehole was unobstructed down to a depth of $1748.0 \mathrm{~m}$ (the beginning of the $4{ }^{1}{ }_{2}$ " filter column). According to hydrogeological documentation, the filter column should have been "suspended" at a depth of $1749.8 \mathrm{~m}$. As a result of testing the filter column with a lead impression block, it was found that the column was obstructed with material at the depth of $1899 \mathrm{~m}$, but that material was then flushed down to $2000 \mathrm{~m}$. In the 2000-2002.4 m interval (final borehole depth according to hydrogeological documentation) the borehole was obstructed and this was probably the bottom of the hole.

After the obstruction had been cleared, geophysical studies (Dziedzic 2012) were initiated to determine the technical condition of the casing and the effectiveness of casing cementation. To this end, the borehole was logged using the following tools:

- MIT-60 multi-finger imaging tool in the $0-1749 \mathrm{~m}$ interval;

- MIT-24 multi-finger imaging tool in the 1749-2002, 1 m interval;

- magnetic thickness tool (MTT);

- radial bond tool (RBT);

- temperature logging tool (TLT);

- KITA inclinometer.

On the basis of the measurements recorded in the Poręba Wielka IG-1 well, the technical condition of casing was assessed as good and its internal diameter (ID) was estimated to be in line with catalogue data.

After the planned geophysical measurements and hydrogeological surveys had been carried out, the original wellhead, which had been dismantled shortly after the start of reconstruction works, was replaced with a new one, adapted for geothermal water extraction. The dismantled wellhead was a typical oil wellhead (Fig. 12). 


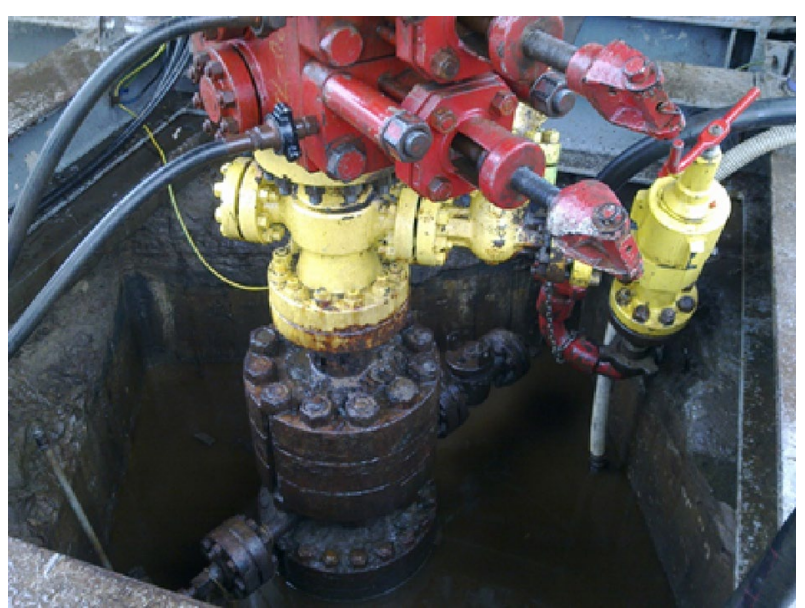

Fig. 12 Lower part of the original Poręba Wielka IG-1 wellhead together with a flange connection to the casing head (photo: B. Bielec)

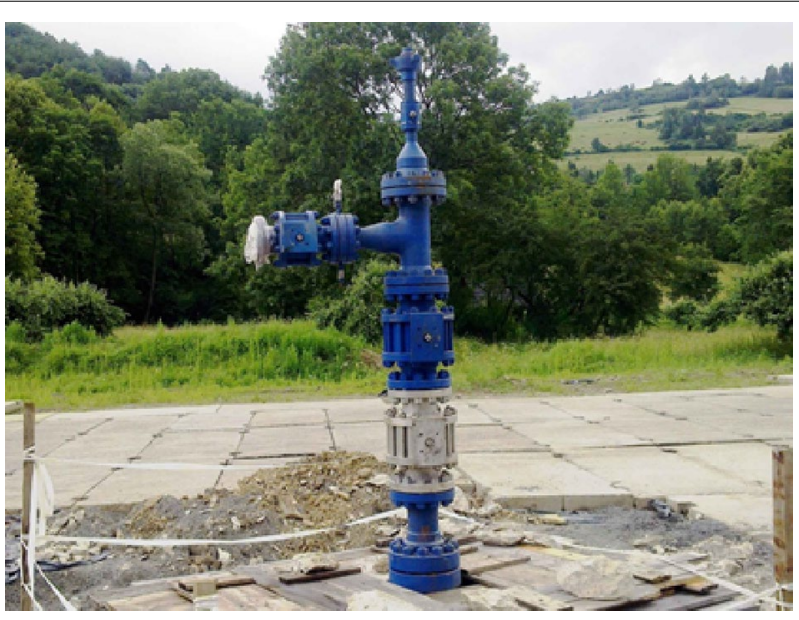

Fig. 13 New wellhead of the Poręba Wielka IG-1 well (photo: B. Bielec)

In connection with the possible future use of the Poręba Wielka IG-1 well as an injection well, a decision was made to install a partly acid-resistant new wellhead (lower part + first valve) due to the high water mineral content of ca. $23-24 \mathrm{~g} / \mathrm{dm}^{3}$ (Fig. 13). Prior to assembly, a pressure test at an operating pressure of $10 \mathrm{MPa}$ was conducted.

As a result of the work conducted, the well was brought to good technical condition (Chruściel 2012), the appropriate wellhead was installed, and the following production resources were documented and approved:

- chemical type of water: $\mathrm{Cl}-\mathrm{HCO}_{3}-\mathrm{Na}, \mathrm{I}$;

- water mineral content: $23-24 \mathrm{~g} / \mathrm{dm}^{3}$;

- water temperature at the wellhead: $42.1{ }^{\circ} \mathrm{C}$ at $Q=16.1 \mathrm{~m}^{3} / \mathrm{h}$;

- static water level in a heated borehole: $1060.53 \mathrm{~m}$ a.s.l. (at land elevation of $517.43 \mathrm{~m}$ a.s.l., artesian pressure is about $5.4 \mathrm{MPa}$ ). 
For the Poręba Wielka IG-1 well, from which water is extracted at a rate of $16.1 \mathrm{~m}^{3}$ / hour at depression $\mathrm{S}=511.9 \mathrm{~m}$, the theoretically determined radius of investigation is 1048 m. Currently (2019), the well's owner, i.e., Gorczańskie Wody Termalne Sp. z o.o., holds a concession for the extraction of water from the Poręba Wielka GT-1 well, but the production has not commenced yet. Work is underway to start extraction. Geothermal water from the well will be used primarily for balneotherapy. In the future, recreational swimming pools will be opened as well.

\section{Biały Dunajec PAN-1 well}

The Biały Dunajec PAN-1 well is an example of reconstruction effected through the repair of damaged casing. The well was drilled by MEERI PAS in 1990 to a depth of $2394 \mathrm{~m}$ and was operated within the PEC Geotermia Podhalańska S.A. system as an injection well until 2003 when it was found that the casing of the $95 / 8$ " column was leaking. The well was taken out of service and reconstructed in 2011 in order to repair the damaged casing by inserting $7 "$ pipes and cementing them (Dubiel et al. 2012). In the following years, the well did not operate properly (a decrease in absorption capacity from the original value of approx. $200 \mathrm{~m}^{3} / \mathrm{h}$ to around a dozen $\mathrm{m}^{3} / \mathrm{h}$ ) due to the obstruction caused by a fragment of drill string (approx. $240 \mathrm{~m}$ ) left in the borehole. Therefore, a decision was made to carry out reconstruction works consisting in closing off the lower section of the borehole and its directional deepening down from the depth of $2136 \mathrm{~m}$, which made a new section of the reservoir accessible down to a $2500 \mathrm{~m}$ TVD (Fig. 14). In 2013, the operator of the PEC Geotermia Podhalańska S.A. geothermal system carried out reconstruction work on the basis of a directional well deepening design. During the work, it was found that the borehole needed to be additionally deepened by approximately $125 \mathrm{~m}$, i.e., to a depth of $2625 \mathrm{~m}$ TVD in order to considerably increase the interval in which the reservoir was accessible (Bujakowski et al. 2015).

Drilling work related to the deepening of the Biały Dunajec PAN-1 injection well was divided into two stages. In the first stage, an attempt was made to unblock the space between the $5^{\prime \prime}$ drill string assembly left in the borehole and the borehole wall. To that end, an assembly with a milling head $82 \mathrm{~mm}$ in diameter was lowered into the borehole and the 2152-2161.7 m interval was cleared. Subsequently, the drilling fluid was replaced with water, and test pumping and absorption capacity test were performed. Unsatisfactory results were obtained (pumping capacity of approx. $60 \mathrm{~m}^{3} / \mathrm{h}$ and absorption capacity of $24 \mathrm{~m}^{3} / \mathrm{h}$ at injection pressure of $60 \mathrm{bar}$ ), and therefore a decision was made to commence the second stage of works, i.e., the drilling of a directional borehole. First of all, a cement plug was set up in the 2024-2152 m interval. The purpose of the work was, on the one hand, to seal the perforation of the lower section of the $95 / 8$ ' casing carried out in 2011 during the first reconstruction of the borehole, and on the other hand to enable a directional borehole with an "S" trajectory to be drilled (Fig. 14). After the cement had set, the plug was drilled within the 2024-2135 m interval $\left(9^{5} / 8_{8}^{\prime \prime}\right.$ casing shoe) and then an assembly with a downhole motor and a $5 \% / 8$ drill was used in order to perform directional drilling.

During the drilling process, inspections and measurements were carried out on an ongoing basis, including the measurement, logging and real-time processing of drilling 


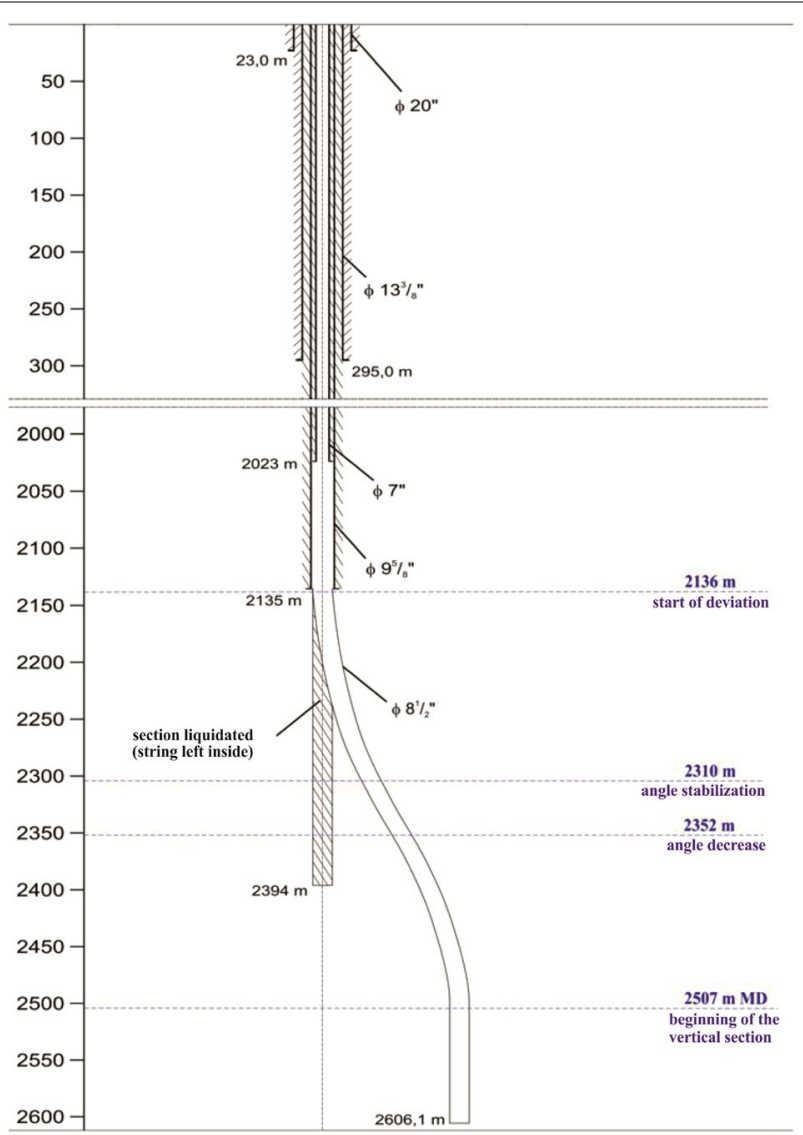

Fig. 14 Schematic structure of the Biały Dunajec PAN-1 well post-reconstruction (based on Bujakowski et al. 2015)

and geological parameters and gas profiling. Since directional drilling to the depth of $2500 \mathrm{~m}$ did not result in satisfactory well injection capacity, on the basis of additional analysis of geological and hydrogeological data it was decided to drill further to a depth of 2625 m TVD (Bujakowski et al. 2014). Ultimately, the Biały Dunajec PAN-1 well was drilled to a MD (measured depth) of $2606.1 \mathrm{~m}$ (2592.8 m TVD).

In order to determine the hydrogeological parameters of the geothermal water reservoir, two injection capacity tests and one hydrodynamic test were performed. The first (preliminary) injection capacity test was performed shortly after the drilling had been completed in October 2014, while the main injection capacity test was conducted in January 2015. Injection capacity test and hydrodynamic test results are presented in Table 2. As a result of the reconstruction of the damaged Biały Dunajec PAN-1 well, the operator PEC Geotermia Podhalańska S.A. managed to make it fully suitable for operation in a doublet arrangement, documenting injection capacity of $375 \mathrm{~m}^{3} / \mathrm{h}$ at an injection pressure of $6.3 \mathrm{MPa}$. 
Table 2 Summary of the results of hydrogeological tests conducted in the Biały Dunajec PAN-1 well after its reconstruction in 2015 (Bujakowski et al. 2015)

\begin{tabular}{lrll}
\hline Step & Flow rate $\left(\mathbf{m}^{\mathbf{3}} \mathbf{h}\right)$ & $\begin{array}{l}\text { Pressure at the wellhead } \\
\text { in the final phase of the step } \\
\text { (bar) }\end{array}$ & Time (hh:mm) \\
\hline Preliminary injectivity test & 31.0 & & \\
I & 100.0 & 20.8 & $01: 00$ \\
I| & 131.0 & 23.9 & $00: 55$ \\
III & & 26.7 & $00: 30$ \\
General injectivity test & 189.0 & & $00: 50$ \\
I & 280.0 & 30.8 & $01: 30$ \\
I| & 363.0 & 45.0 & $02: 40$ \\
III & 59.0 & $02: 10$ \\
Hydrodynamic (pressure buildup) test & & $01: 15$ \\
I & 96.0 & 17.4 & $02: 00$ \\
Pressure buildup after I step & 0.0 & 19.5 & $01: 15$ \\
I| & 168.0 & 12.5 & $01: 00$ \\
Pressure buildup after II step & 0.0 & 19.5 & $01: 00$ \\
III & 240.0 & 4.3 & \\
Pressure buildup after III step & 0.0 & 19.5 & \\
\hline
\end{tabular}

\section{Czarny Potok GT-1 well}

The Czarny Potok GT-1 well was drilled on the basis of a design for geological works, pursuant to a concession for exploration and recognition of thermal water resources. The geological work performed made it possible to determine the geological structure of deep flysch formations within the Magura Unit in Krynica-Zdrój. At the same time, it was also the first deep borehole $(2853.3 \mathrm{~m})$ drilled in that area. Unfortunately, the goal of the works covered by the concession was not achieved. In connection with the negative geological effect, i.e., the absence of thermal water inflow into the Czarny Potok GT-1 well, a project for using the well as a borehole heat exchanger (BHE) was developed. The aim of the project work carried out in 2012 by MEERI PAS in Kraków was to extract the Earth's heat from the well by adapting its existing structure to the needs of a coaxial BHE. This is the first task of this type undertaken in Poland, although analytical works related to the development of deep boreholes for geothermal purposes have already been undertaken (Śliwa and Kotyza 2003; Gonet et al. 2011; Śliwa et al. 2018). This deep BHE configuration has been investigated and proven viable in various locations around Europe (Śliwa et al. 2014). These solutions have been and are being analyzed, especially with respect to the adaptation of former oil wells (Bauer et al. 2011, Kohl et al. 2002). BHE technology has been implemented and operated since the 1990s, among others in Prenzlau (Germany). The decision to implement this solution was made because the reservoir layer turned out to be almost waterless. In addition, for various reasons, also related to rising costs of extracting energy from oil and gas resources during the so-called energy crisis of the late 1990s, ground heat exchangers were put into operation in other countries, e.g. in Weggis and Bad Weisbach in Switzerland (Kohl et al. 2000; 2002) and Altheim (Austria). In Germany, similar projects were carried out in Aachen (Dijkshoorn et al. 2013), in Arnsberg (Doelling and Schulte 2010) and in Prenzlau (Schneider et al. 1996). Obtaining 
heat from the Earth by means of downhole heat exchangers is an interesting solution also because it offers an alternative for diversifying heat supply in many areas of Germany, Austria and Switzerland.

The assumptions underlying the conversion of the negative Czarny Potok GT-1 well into a deep borehole heat exchanger included the utilization of renewable energy from the installation in the planned recreation and sports center. The concept for the construction of a coaxial BHE, taking into account the existing well structure (casing), and the related design assumptions were developed by MEERI PAS Division of Renewable Energy Sources in June 2011 (Bujakowski et al. 2011). In this work, several variants for the installation of coaxial downhole tubing have been developed, through which the working medium was to be pumped from the outside. On the basis of the model studies carried out, it was estimated that the best case scenario would be around $250-300 \mathrm{~kW}$ of thermal power. It was assumed that the well would be developed to a depth of $2600 \mathrm{~m}$ and that the design of the downhole coaxial heat exchanger would be tight-the medium (circulating water) would not come into direct contact with the rock formation. The water was to be heated by contact with the steel casing (Fig. 15). Water with a low mineral content was to be used as a medium to extract heat from the rock mass.

Direct extraction of Earth's heat by means of a coaxial borehole heat exchanger with a closed water circuit is safe for the environment. The heat exchanger designed was to consist of steel tubing constituting its external casing and production tubing-thin coaxial pipes placed in the casing. The external column in this case was to be provided by the current structure of the Czarny Potok GT-1 well. Additional insulating medium (technical nitrogen or mineral oil, Fig. 15) was to be present between the external and internal tubing in order to limit heat losses during water flow in the borehole. As concerns the construction of the coaxial borehole heat exchanger, the key role was to be played by the external column, consisting partly of the casing left in the Czarny Potok GT-1 well and partly of a system of coaxial internal columns.

The project developed was granted a patent protection (Bujakowski et al. 2016); three variants of technical solutions for the exchanger were presented in the patent depending on borehole depth and structure. However, the project has not yet been implemented.

\section{Discussion}

Drilling works are the most expensive element of the geothermal plant construction. In Polish conditions, the share of these costs is usually over 50\% of the cost of the entire plant. The costs of drilling are increasing with well depth. In Fig. 16, a summary of the actual costs incurred for the construction of several new wells and reconstructed wells is presented. These values are presented against the background of the expenditures accepted for co-financing by the National Fund for Environmental Protection and Water Management (NFEP\&WM) - a state-owned institution financially supporting the implementation of drilling works. The green dashed curve plotted on Fig. 16 is based on the NFEP\&WM guidelines (NFEP\&WM 2020) and was developed based on average data from the drilling industry. Because each project is characterized by individual conditions, therefore the expenditure on its implementation are verified by tenders, which is why we observe deviations in actual costs from the NFEP\&WM curve. 


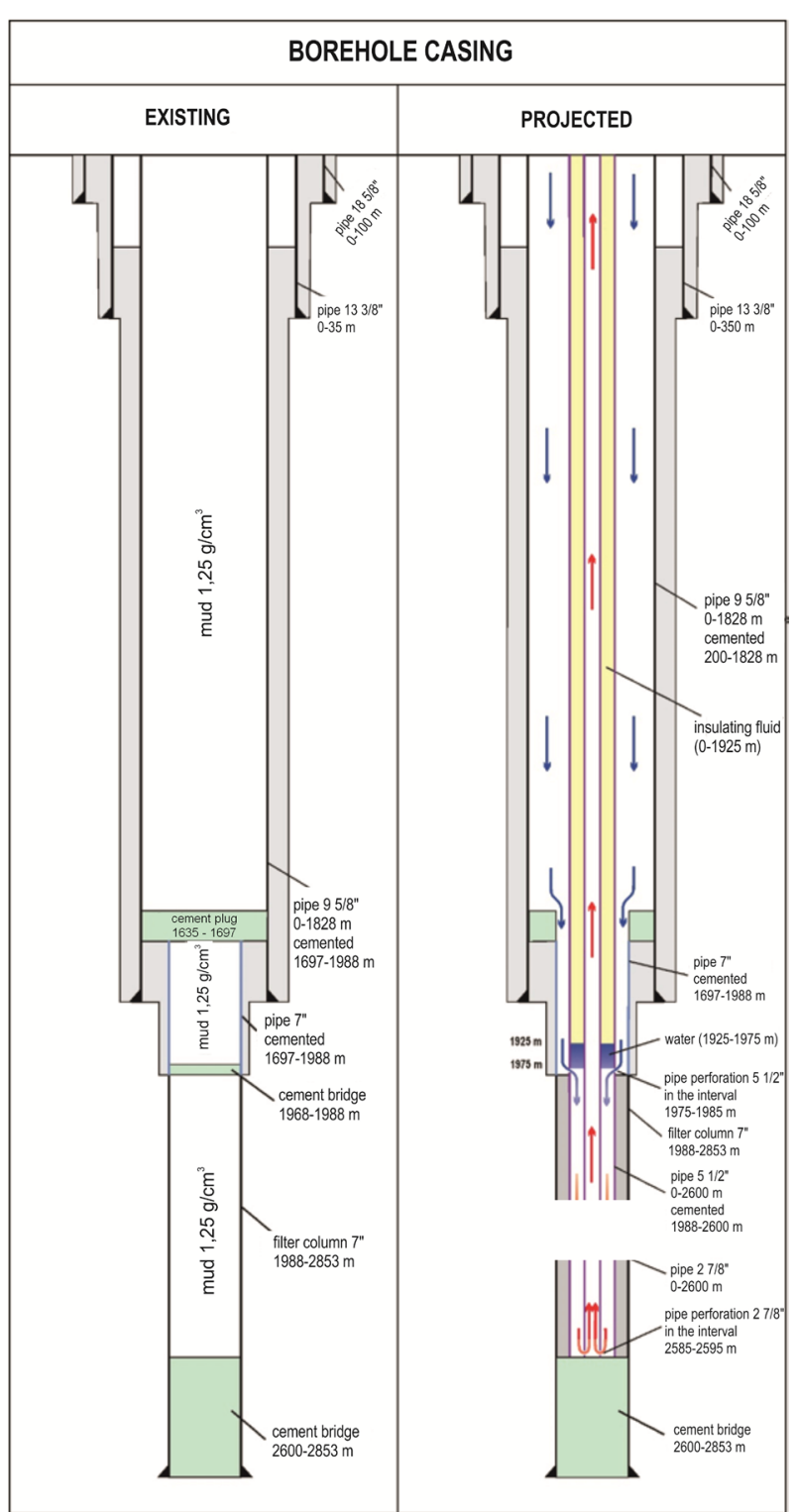

Fig. 15 Schematic design of the downhole coaxial heat exchanger in the Czarny Potok GT-1 well (Bujakowski et al. 2011)

The data in Fig. 16 show that the costs of reconstruction are much lower than the costs of drilling a new well. This is valuable, however, insufficient information to make a reconstruction decision. The question is what is obtained for these outlays? The purpose of the reconstruction is to obtain the maximum effect expressed mainly by the inflow of geothermal waters with minimal costs of works and materials. To compare the effects of the reconstruction depending on the expenditure incurred, the reconstruction cost factor was estimated, expressed in net costs incurred for obtaining $1 \mathrm{~m}^{3}$ of geothermal water or installed $1 \mathrm{~kW}$ of thermal capacity (the case of the project for the reconstruction of the Czarny Potok GT-1 well). The smaller the net cost factor, the better the drilling effect. Similar calculations were performed for a new well, with the parameters of a 


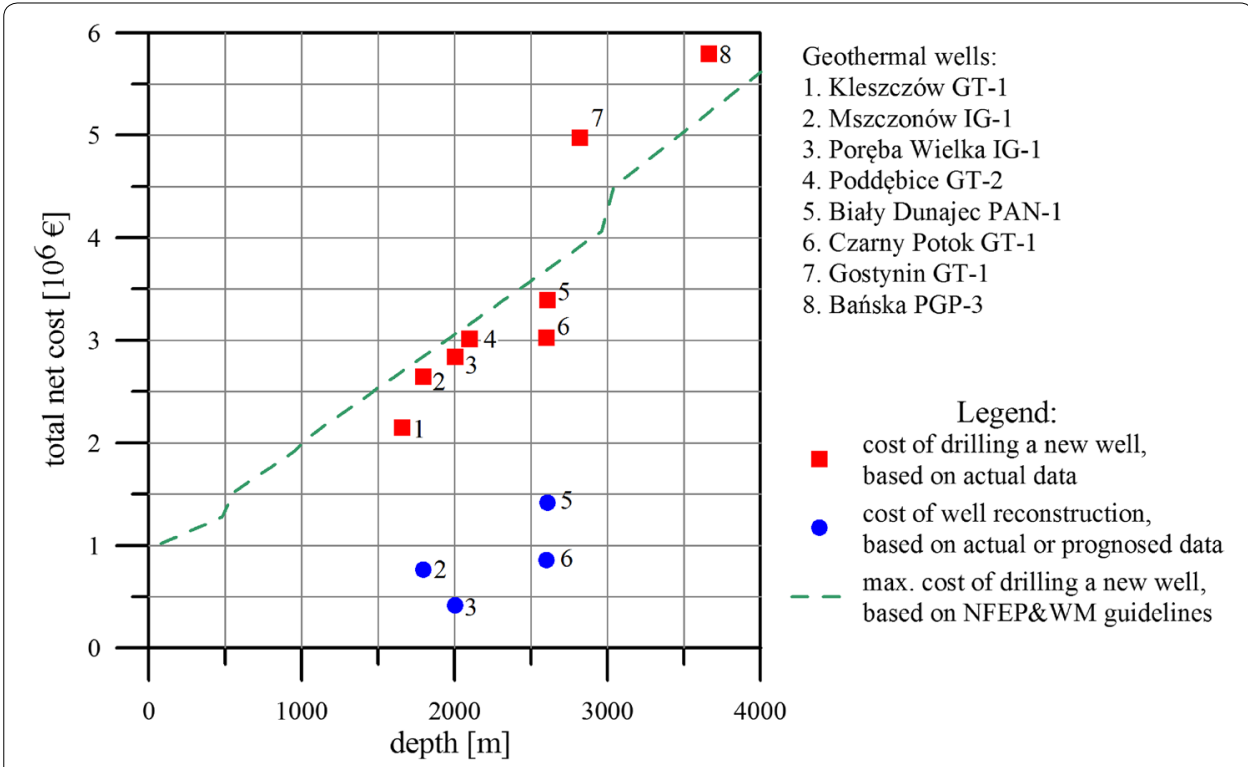

Fig. 16 A summary of the actual costs of drilling and reconstructing selected geothermal wells in Poland

Table 3 Comparison of costs of carried out or planned reconstructions with the costs of a drilling a new well (according to costs updated for 2020)

\begin{tabular}{|c|c|c|c|c|c|c|}
\hline \multirow[t]{2}{*}{ Well (depth) } & \multicolumn{3}{|c|}{ Reconstructed well } & \multicolumn{3}{|c|}{ New well in that area } \\
\hline & Net cost $(\mathrm{M} €)$ & $\begin{array}{l}\text { Effect } \\
\text { obtained } \\
\left(\mathrm{m}^{3} / \mathrm{h}\right)\end{array}$ & $\begin{array}{l}\text { Net cost } \\
\text { factor }(k € / \\
\left.\mathrm{m}^{3}\right)\end{array}$ & Net cost (M€) & $\begin{array}{l}\text { Effect } \\
\text { expected } \\
\left(\mathrm{m}^{3} / \mathrm{h}\right)\end{array}$ & $\begin{array}{l}\text { Net cost } \\
\text { factor }(k € / \\
\left.\mathrm{m}^{3}\right)\end{array}$ \\
\hline $\begin{array}{l}\text { Mszczonów } \\
\text { IG-1 } \\
\text { (1793 m) }\end{array}$ & 0.77 & 60.0 & 12.8 & 2.65 & $>150 \mathrm{~m}^{3} / \mathrm{h}$ & 17.7 \\
\hline $\begin{array}{l}\text { Poręba } \\
\text { Wielka IG-1 } \\
(2002 \text { m) }\end{array}$ & 0.42 & 16.1 & 26.1 & 2.84 & $10-20 \mathrm{~m}^{3} / \mathrm{h}$ & 180.0 \\
\hline $\begin{array}{l}\text { Biały Dunajec } \\
\text { PAN-1 } \\
\text { (2606,1 m } \\
\text { MD } \\
2592,8 \mathrm{~m} \\
\text { TVD) }\end{array}$ & 1.42 & 375.0 & 3.8 & 3.40 & ca. $400 \mathrm{~m}^{3} / \mathrm{h}$ & 8.5 \\
\hline $\begin{array}{l}\text { Czarny Potok } \\
\text { GT-1 } \\
(2600 \mathrm{~m})\end{array}$ & 0.86 & $250-300 \mathrm{~kW}_{\mathrm{t}}$ & $3.0\left(\mathrm{k} \in / \mathrm{kW}_{\mathrm{t}}\right)$ & 3.02 & $250-300 \mathrm{kWt}$ & $10.0(\mathrm{k} € / \mathrm{kWt})$ \\
\hline
\end{tabular}

a Negative well (project for coaxial hole heat exchanger was designed) - drilling cost in the years $2010 \div 2011-3.0 \mathrm{M} €$ (reconstruction project not implemented)

b Estimated values

reconstructed well. In this case, the costs were determined on the basis of known actual costs incurred for drilling the well at a similar location and depth. The expected capacities of new wells were also estimated based on confirmed parameters obtained in neighboring wells. In this way, the results for three locations where reconstruction was carried out were compared and for the Czarny Potok GT-1 well where reconstruction works were designed and priced but not performed (Table 3). 
In all the cases analyzed, higher values of the net cost factor of the new well were found. The best result is shown in the reconstruction of the Poręba Wielka IG-1 well, where the cost of reconstruction is almost 7 times less than the cost of a new well $\left(26.1 \mathrm{k} € / \mathrm{m}^{3}\right.$ and $180 \mathrm{k} € / \mathrm{m}^{3}$, respectively). In this case, relatively small inflows of water are mainly of recreational and balneotherapeutic importance, and to a small extent energetic, therefore the profitability of making them available must be separately analyzed. Another good example of successful reconstruction is the case of the Biały Dunajec PAN-1 well, where initially approved injection capacity was almost doubled at less than half of the cost of drilling a new well. The reconstruction of the Mszczonów IG-1 well carried out in 2000 have a net cost factor of $12.8 \mathrm{k} € / \mathrm{m}^{3}$, while drilling a new well is expected to have a net cost factor around $18.0 \mathrm{k} € / \mathrm{m}^{3}$. In this case, the $60 \mathrm{~m}^{3} / \mathrm{h}$ flow rate obtained at the stage of reconstruction turned out to be optimal and sufficient to cover the heat demand of the city with about 5700 inhabitants. Larger outlays, which would certainly result in a much higher flow rate of reservoir water, would result in unprofitability of the entire investment of the geothermal plant, due to the inability to sell heat.

The fourth analyzed reconstruction concerns the implementation of a deep borehole heat exchanger in the negative Czarny Potok GT-1 well. The anticipated effects of making a new well just for the construction of a deep borehole heat exchanger do not provide a basis for rational operation. The effects of the reconstruction of such a well estimated at about $300 \mathrm{~kW}$ of thermal power and the net cost factor-about $3.0 \mathrm{k} € / \mathrm{kW}$ indicate some possibility of recovering expenditures incurred for the negative well. However, it is definitely unprofitable to drill such a well with the intention of assembling a borehole heat exchanger.

\section{Conclusions}

In Poland, 6 geothermal plants operate which generate and sell heat for district heating purposes: PEC Geotermia Podhalańska SA, Geotermia Pyrzyce sp. z o.o., Geotermia Mazowiecka SA, Geotermia Uniejów sp. z o.o., Geotermia Stargard sp. z o.o. and Geotermia Poddębice sp. z o.o. It is only in the geothermal system in Poddębice that no well reconstructions have been undertaken. At the remaining plants, such works were carried out, and in the Podhale region, Mszczonów and Uniejów they played a key role in the early phase of the plants' commissioning. At Pyrzyce and Stargard, after a period of trouble-free operation geothermal doublets were damaged and subsequently successfully repaired. Cost analysis of drilling a new well instead of well reconstruction indicates the profitability of reconstruction, for which the net cost factor may be 2-3 times lower than in case of drilling a new well. From the above, it follows that reconstruction measures are of considerable importance for the stable commercial use of geothermal energy. The experience gained and the variety of methodologies related to the reconstruction procedures carried out in Poland provide a basis for a serious analysis and discussion of the possibility and expediency of developing old disused deep wells which number over 8000 in Poland. 
Research Institute, Polish Academy of Sciences; MIT: Multi-finger imaging tool; MTT: Magnetic thickness tool; O.R.: Outer radius; PGI-NRI: Polish Geological Institute-National Research Institute; RBT: Radial bond tool; PL: Production logging; SPT: Stack pressure tool; TLT: Temperature logging tool; TVD: True vertical depth.

\section{Acknowledgements}

The authors would like to thank their colleagues from the MEERI PAS Division of Renewable Energy Sources for their help in preparing the article.

\section{Authors' contributions}

WB was the initiator and designer the article concept as well as the main author or co-author of most sections within the article. BB and LP were co-authors of the paragraphs describing reconstruction of respective boreholes and contributed to the cost analysis of a new well drilling and well reconstruction. MM co-authored the introduction, prepared paragraph describing geothermal resources in Poland, acquired aggregated borehole data and made its analysis as well as compiled the final version of the manuscript. All authors read and approved the final manuscript.

\section{Funding}

The paper was prepared: within the framework of statutory research at the MEERI PAS Division of Renewable Energy Sources in 2019, financed from state funds; thanks to funds for financing scientific research at the AGH University of Sciences and Technology Faculty of Geology, Geophysics and Environmental Protection in 2019 (Research Grant No. 16.16.140.315)

\section{Availability of data and materials}

The part of the data that support the findings of this study are available free of charge from the Polish Geological Institute-National Research Institute webservers and geoportals, i.e., shapefiles can be downloaded from the CBDG Download Manager (http://dm.pgi.gov.pl/), wells search engine: PGI-NRI Boreholes (http://otworywiertnicze.pgi.gov. pl/), geological GIS data (http://geologia.pgi.gov.pl). The data from boreholes drilling, logging and reconstruction are properties of the respective companies, and so are not publicly available. Part of these data are however available from the authors for view only, upon reasonable request and with permission of respective companies.

\section{Competing interests}

The authors declare that they have no competing interests.

\section{Author details}

${ }^{1}$ Mineral and Energy Economy Research Institute, Polish Academy of Sciences, Wybickiego 7A Str., 31-261 Kraków, Poland. ${ }^{2}$ Department of Fossil Fuels, Faculty of Geology, Geophysics and Environmental Protection, AGH University of Science and Technology, Mickiewicza 30 Ave., 30-059 Kraków, Poland.

Received: 21 January 2020 Accepted: 12 March 2020

Published online: 24 March 2020

\section{References}

Agemar T, Weber J, Schulz R. Deep geothermal energy production in Germany. Energies. 2014;7:4397-416. https:// doi.org/10.3390/en7074397.

Barbacki A, Bujakowski W, Pająk L. Atlas zbiorników wód geotermalnych małopolski. Kraków: IGSMiE PAN; 2006. Barbier E. Geothermal energy technology and current status: an overview. Renew Sustain Energy Rev. 2002;6(1-2):365. https://doi.org/10.1016/S1364-0321(02)00002-3.

Bauer D, Heidemann W, Müller-Steinhagen H, Diersch H-JG. Thermal resistance and capacity models for borehole heat exchangers. Int J Energy Res. 2011;35(4):312-20. https://doi.org/10.1002/er.1689.

Bielec B, Operacz A. Newest recognition of exploitation parameters based on Chochołów PIG-1 borehole in the aspect of temperature effect. Inżynieria Ekologiczna. 2018;19(6):145-52. https://doi.org/10.12912/23920 $629 / 99550$.

Bujakowski W. (Ed.). Wybrane problemy wykorzystania geotermii - część 1. Studia, Rozprawy, Monografie; no 76 Kraków: IGSMiE PAN; 2000

Bujakowski W, (Ed.). Badania naukowe i ocena występowania oraz możliwości zagospodarowania energii geotermalnej przy wsparciu innych OZE w kontekście zrównoważonego rozwoju gmin powiatu piotrkowskiego. Kraków: IGSMiE PAN Kraków; 2014 (unpublished raport).

Bujakowski W. Geologiczne, środowiskowe i techniczne uwarunkowania projektowania i funkcjonowania zakładów geotermalnych w Polsce. Studia, Rozprawy, Monografie; no 193 Kraków: IGSMiE PAN; 2015.

Bujakowski W, Barbacki A, Bielec B, Graczyk S, Hołojuch G, Kępińska B, Kotowski T, Pająk L, Tomaszewska B. Projekt prac geologicznych w celu poszukiwania i rozpoznania zasobów wód termalnych w rejonie Łowicza. Kraków: IGSMiE PAN Kraków; 2009 (unpublished raport).

Bujakowski W, Bielec B, Graczyk S, Hołojuch G, Kępińska B, Tomaszewska B. Projekt prac geologicznych celu aktualizacji zasobów eksploatacyjnych wód termalnych dla otworu Poręba Wielka IG-1. Kraków: IGSMiE PAN Kraków; 2010 (unpublished raport).

Bujakowski W, Bielec B, Hołojuch G, Graczyk S, Kępińska B, Pajak L, Tomaszewska B. Projekt prac geologicznych na wykorzystanie ciepła ziemi otworem Czarny Potok GT-1. Kraków: IGSMiE PAN Kraków; 2011 (unpublished raport).

Bujakowski W, Balcer M, Bielec B. Ocena zmian stanu technicznego rur okładzinowych w trakcie wieloletniej eksploatacji odwiertu geotermalnego Mszczonów IG-1. Technika Poszukiwań Geologicznych, Geotermia, Zrównoważony Rozwój. 2013a;52(1):83-90. 
Bujakowski W, Balcer M, Bielec B. Porównawczy obraz produktywności poziomu wodonośnego na podstawie badań zestawem sond PL i sondą MIT60 na przykładzie odwiertu geotermalnego Mszczonów IG-1. Technika Poszukiwań Geologicznych, Geotermia, Zrównoważony Rozwój. 2013b;52(1):73-82.

Bujakowski W, Barbacki A, Bielec B, Hołojuch G, Kasztelewicz A, Kępińska B, Miecznik M, Pająk L, Skrzypczak R, Tomaszewska B. Dodatek nr 1 do dokumentacji hydrogeologicznej podziemnych wód mineralnych z utworów paleogenu otwór Rabka IG-1 i utworów kredy-paleogenu - otwór Poręba Wielka IG-1 w związku z ustaleniem nowych zasobów eksploatacyjnych wód termalnych otworu Poręba Wielka IG-1. Kraków: IGSMiE PAN Kraków; 2013c (unpublished raport).

Bujakowski W. (Ed.), Tomaszewska B. (Ed.), Barbacki A, Bielec B, Borsukiewicz-Gozdur A, Ciężkowski W, Chowaniec J, Czerwińska B, Franus W, Freiwald P, Górecki W, Hajto M, Hołojuch G, Kaczmarek R, Kasztelewicz A, Kępińska B, Kujawa T, Leśniak G, Mazurek R, Miecznik M, Nowak W, Przelaskowska A, Skrzypczak R, Sowiżdżał A, Stachel AA, Wiśniewski S. Atlas wykorzystania wód termalnych do skojarzonej produkcji energii elektrycznej i cieplnej w układach binarnych w Polsce (Atlas of the possible use of geothermal waters for combined production of electricity and heat using binary systems in Poland). Kraków: Jak; 2014.

Bujakowski W, Bielec B, Hołojuch G, Tomaszewska B. Projekt robót geologicznych na wykonanie dodatkowego pogłębienia otworu chłonnego "Biały Dunajec PAN-1". Kraków: IGSMiE PAN Kraków; 2014 (unpublished raport).

Bujakowski W, Barbacki A, Bielec B, Hołojuch G, Kasztelewicz A, Kępińska B, Lankof L, Miecznik M, Pająk L, Skrzypczak R, Tomaszewska B. Dokumentacja hydrogeologiczna określająca warunki hydrogeologiczne w związku z wtłaczaniem wód do górotworu otworem Biały Dunajec PAN-1. Kraków: IGSMiE PAN Kraków; 2015 (unpublished raport).

Bujakowski W, Pająk L, Tomaszewska B, Hołojuch G, Łuszczewski J. Otworowy wymiennik ciepła (Hole Heat Exchanger). Patent Application P.401721. Bulletin of Polish Patent Office, No. 11(1054). Polish patent PAT.222919, 30.09.2016. http://regserv.uprp.pl/register/application?number=P.401721.

Bujakowski W, Balcer M, Barbacki A, Bielec B, Tomaszewska B, Pająk L, Skrzypczak R, Dendys M, Kasztelewicz A, Dajek B. Otwór geotermalny Mszczonów IG-1 - rekonstrukcja i wieloletnia eksploatacja. Studia, Rozprawy, Monografie; no 206 Kraków: IGSMiE PAN; 2017.

Bujakowski W, Bielec B, Balcer M. Rational management of geothermal waters after their energetic use - preliminary results of the project Geotermia Mazowiecka SA. Gospodarka Surowcami Mineralnymi-Mineral Resources Management. 2020;36(1):123-34. https://doi.org/10.24425/gsm.2020.132555.

Capuano LE Jr. Geothermal well drilling. In: DiPippo R, editor. Geothermal power generation-developments and innovation. Amsterdam: Elsevier; 2016. p. 107-39. https://doi.org/10.1016/B978-0-08-100337-4.00005-X.

Caulk RA, Tomac I. Reuse of abandoned oil and gas wells for geothermal energy production. Renew Energy. 2017;112:388-97. https://doi.org/10.1016/j.renene.2017.05.042.

Chruściel K, Stramecka B, Miziołek E, Dobrowolska E. Ocena stanu technicznego odwiertu na podstawie pomiarów geofizyki wiertniczej w otworze Poręba Wielka IG-1. Krosno: Geofizyka Kraków Sp. z o.o., Baza Geofizyki Wiertniczej Krosno; 2012 (unpublished raport).

Dijkshoorn L, Speer S, Pechnig R. Measurements and design calculations for a deep coaxial borehole heat exchanger in Aachen. Germany. Int J Geophys. 2013. https://doi.org/10.1155/2013/916541.

Doelling R, Schulte I. Deep Groundsourced heat exchanger with coaxial pipe, closed water circuit-improvement proposals in project development and technical pipe conception. In: Proceedings world geothermal congress 2010; Bali, Indonesia, 25-29 April 2010.

Dubiel S, Luboń K, Luboń W, Wartak W. Problemy rekonstrukcji odwiertów geotermalnych na przykładzie odwiertu Biały Dunajec PAN-1. AGH Drilling Oil Gas. 2012;29(1):115-26.

Dziedzic E. Ocena stanu zacementowania rur 6 5/8" w otworze Poręba Wielka IG-1. Krosno: Geofizyka Kraków Sp. z 0.0., Baza Geofizyki Wiertniczej Krosno; 2012 (unpublished raport).

Federal Institute for Geosciences and Natural Resources (BGR). Borehole Map Germany. https://boreholemap.bgr.de/. Accessed 17 Dec 2019.

Franko O, Remšik A, Fendek M, editors. Atlas of geothermal energy of Slovakia. Dionýz Štúr Institute of Geology: Bratislava; 1995.

Fridleifsson IB, Freeston DH. Geothermal energy research and development. Geothermics. 1994;23(2):175-214. https:// doi.org/10.1016/0375-6505(94)90037-X.

Gonet A, Śliwa T, Stryczek S, Sapińska-Śliwa A, Jaszczur M, Pająk L, Złotkowski A. Metodyka identyfikacji potencjału cieplnego górotworu wraz z technologią wykonania i eksploatacji otworowych wymienników ciepła. Kraków: AGH University of Science and Technology; 2011.

Goosen M, Mahmoudi H, Ghaffour N. Water Desalination using geothermal energy. Energies. 2010;3:1423-42. https://doi. org/10.3390/en3081423

Gordienko WV, Gordienko IV (eds.). Geothermal Atlas of Ukraine. Kiev: National Academy of Sciences of Ukraine, Institute of Geophysics of S. I. Subbotin; 2004.

Górecki W, editor. Atlas zasobów geotermalnych formacji mezozoicznej na Niżu Polskim (Atlas of geothermal resources of Mesozoic formations in the Polish Lowlands). Kraków: AGH University of Science and Technology; 2006a.

Górecki W, editor. Atlas zasobów geotermalnych formacji paleozoicznej na Niżu Polskim (Atlas of geothermal resources of Paleozoic formations in the Polish Lowlands). Kraków: AGH University of Science and Technology; 2006b.

Górecki W, editor. Atlas zasobów wód i energii geotermalnej Karpat Zachodnich (Atlas of geothermal waters and energy resources in the Western Carpathians). Kraków: AGH University of Science and Technology; 2011.

Górecki W, editor. Atlas geotermalny zapadliska przedkarpackiego (Geothermal atlas of the Carpathian Foredeep). Kraków: AGH University of Science and Technology; 2012.

Górecki W, editor. Atlas geotermalny Karpat Wschodnich (Geothermal atlas of the Eastern Carpathians). Kraków: AGH University of Science and Technology; 2013.

Górecki W. (ed.), Adamczyk AF, Szczepański A, SzklarczykT. Atlas wód geotermalnych Niżu Polskiego. Kraków: Instytut Surowców Energetycznych AGH University of Science and Technology; 1990.

Górecki W. (ed.), KuźniakT, Łapinkiewicz AP, Maćkowski T, Strzetelski W, SzklarczykT. Atlas zasobów energii geotermalnej na Niżu Polskim. Kraków: Towarzystwo Geosynoptyków „GEOS”; 1995. 
Górecki W, Sowiżdżał A, Hajto M, Wachowicz-Pyzik A. Atlases of geothermal waters and energy resources in Poland. Environ Earth Sci. 2015;74:7487-95. https://doi.org/10.1007/s12665-014-3832-2.

Haenel R, Staroste E, editors. Atlas of geothermal resources in the European Community, Austria and Switzerland. Th. Schäfer: Hannover; 1988.

Hurter S, Heanel R, editors. Atlas of geothermal resources in Europe. Luxemburg: Office for the Official Publications of the European Communities; 2002.

Hurter S, Schellschmidt R. Atlas of geothermal resources in Europe. Geothermics. 2003;32(4-6):779-87. https://doi. org/10.1016/S0375-6505(03)00070-1.

Kępińska B. Warunki termiczne i hydrotermalne podhalańskiego system geotermalnego. Studia, Rozprawy, Monografie; no 135 Kraków: IGSMiE PAN; 2006.

Kohl T, Salton M, Rybach L. Data analysis of the deep borehole heat exchanger plant Weissbad (Switzerland). Proceedings World Geothermal Congress 2000; Kyushu-Tohoku, Japan, May 25-June 10; 2000.

Kohl T, Brenni R, Eugster W. System performance of a deep borehole heat exchanger. Geothermics. 2002;31(6):687-708. https://doi.org/10.1016/S0375-6505(02)00031-7.

Kulcar B, Goricanec D, Krope J. Economy of exploiting heat from low temperature geothermal sources using a heat pump. Energy Build. 2008;40(3):323-9. https://doi.org/10.1016/j.enbuild.2007.02.033.

Lu SM. A global review of enhanced geothermal system (EGS). Renew Sustain Energy Rev. 2018;81(2):2902-21. https:// doi.org/10.1016/j.rser.2017.06.097.

Miecznik M. Model zrównoważonej eksploatacji zbiornika wód geotermalnych w centralnej części Podhala do produkcji energi cieplnej i elektrycznej. Studia, Rozprawy, Monografie; no 202 Kraków: IGSMiE PAN; 2017.

NFEP\&WM. Polska Geotermia Plus. http://nfosigw.gov.pl/oferta-finansowania/srodki-krajowe/programy-priorytetowe/ polska-geotermia-plus/. Accessed 3 Mar 2020.

Nian Y, Cheng W. Evaluation of geothermal heating from abandoned oil wells. Energy. 2018a;142:592-607. https://doi. org/10.1016/j.energy.2017.10.062.

Nian Y, Cheng W. Insights into geothermal utilization of abandoned oil and gas wells. Renew Sustain Energy Rev. 2018b;87:44-60. https://doi.org/10.1016/j.rser.2018.02.004.

Østergaard PA, Lund H. A renewable energy system in Frederikshavn using low-temperature geothermal energy for district heating. Appl Energy. 2011;88(2):479-87. https://doi.org/10.1016/j.apenergy.2010.03.018.

Pajak L, Tomaszewska B, Bujakowski W, Bielec B, Dendys M. Review of the Low-Enthalpy Lower Cretaceous Geothermal Energy Resources in Poland as an Environmentally Friendly Source of Heat for Urban District Heating Systems. Energies. 2020;13(6):1302

Polish Geological Institute-National Research Institute (PGI-NRI). Boreholes. 2019a. http://otworywiertnicze.pgi.gov.pl/. Accessed 17 Dec 2019

Polish Geological Institute-National Research Institute (PGI-NRI). Kartografia geologiczna. 2019b. http://geologia.pgi.gov. pl/arcgis/apps/MapSeries/index.html?appid=8d14826a895641e2be10385ef3005b3c. Accessed 17 Dec 2019.

Poprawa D, Burtan J, Jasionowicz J. Dokumentacja hydrogeologiczna podziemnych wód mineralnych z utworów paleogenu - otwór Rabka IG-1 i utworów kredy-paleocenu - otwór Poręba Wielka IG-1. Kraków: PGI-PRI, O. Karpacki; 1975 (unpublished raport).

Røksland M, Basmoen TA, Sui D. Geothermal energy extraction from abandoned wells. Energy Procedia. 2017;105:244-9. https://doi.org/10.1016/j.egypro.2017.03.309.

Schneider D, Strothöffer T, Broßmann E. Die 2800 m von Prenzlau oder die tiefste Erdwärmesonde der Welt. Geothermische Energy. 1996;16:10-2.

Śliwa T, Kotyza J. Application of existing wells as ground heat source for heat pumps in Poland. Appl Energy. 2003:74(1):3-8. https://doi.org/10.1016/S0306-2619(02)00125-3.

Śliwa T, Rosen MA, Jezuit Z. Use of oil boreholes in the Carpathians in geoenergetic systems: historical and conceptual review. Res J Environ Sci. 2014;8(5):231-42. https://doi.org/10.3923/rjes.2014.231.242.

Śliwa T, Kruszewski M, Zare A, Assadi M, Sapińska-Śliwa A. Potential application of vacuum insulated tubing for deep borehole exchangers. Geothermics. 2018;75:58-67. https://doi.org/10.1016/j.geothermics.2018.04.001.

Solik-Heliasz E. Atlas zasobów energii geotermalnej w rejonie górnośląskim. Utwory neogenu, karbonu i dewonu. Katowice: GIG; 2009

Sowiżdżał A. Geothermal energy resources in Poland-overview of the current state of knowledge. Renew Sustain Energy Rev. 2018;82:4020-7. https://doi.org/10.1016/j.rser.2017.10.070.

Tomaszewska B. The prognosis of scaling phenomena in geothermal system using the geochemical modeling methods. Miner Resour Manag. 2008;24(2):399-407.

Tomaszewska B, Dendys M. Zero-waste initiatives —waste geothermal water as a source of medicinal raw material and drinking water. Desalin Water Treat. 2018;112:12-8. https://doi.org/10.5004/dwt.2018.22216.

Tomaszewska B, Tyszer M. Assessment of the influence of temperature and pressure on the prediction of the precipitation of minerals during the desalination process. Desalination. 2017;424:102-9. https://doi.org/10.1016/j.desal 2017.10.003.

Tomaszewska B, Bodzek M, Rajca M, Tyszer M. Geothermal water treatment. Membrane selection for the RO process. Desalin Water Treat. 2017;64:292-7. https://doi.org/10.5004/dwt.2017.11399.

\section{Publisher's Note}

Springer Nature remains neutral with regard to jurisdictional claims in published maps and institutional affiliations. 